\title{
Republic of Estonia: Selected Issues
}

This Selected Issues paper for the Republic of Estonia was prepared by a staff team of the International Monetary Fund as background documentation for the periodic consultation with the member country. It is based on the information available at the time it was completed on September 27, 2004. The views expressed in this document are those of the staff team and do not necessarily reflect the views of the government of the Republic of Estonia or the Executive Board of the IMF.

The policy of publication of staff reports and other documents by the IMF allows for the deletion of market-sensitive information.

To assist the IMF in evaluating the publication policy, reader comments are invited and may be sent by e-mail to publicationpolicy@imf.org.

Copies of this report are available to the public from

International Monetary Fund • Publication Services

$70019^{\text {th }}$ Street, N.W. • Washington, D.C. 20431

Telephone: (202) 623-7430 • Telefax: (202) 623-7201

E-mail: publications@imf.org Internet: http://www.imf.org

Price: $\$ 15.00$ a copy

\section{International Monetary Fund Washington, D.C.}





\title{
INTERNATIONAL MONETARY FUND \\ REPUBLIC OF ESTONIA
}

\author{
Selected Issues \\ Prepared by Mark Lutz and Emil Stavrev (both EUR) \\ Approved by the European Department \\ September 27, 2004 \\ Contents \\ Page

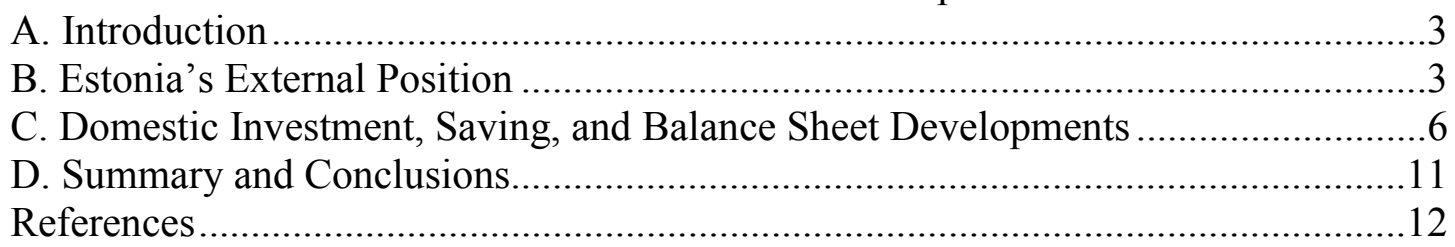

I. Estonia's External Debt and Domestic Balance Sheet Developments .....................................3

II. Labor and Product Market Flexibility and Productivity Catch-up in the Run-up to the

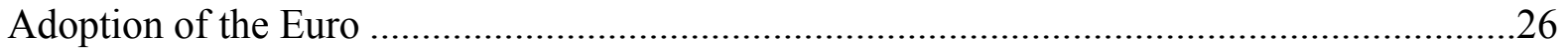

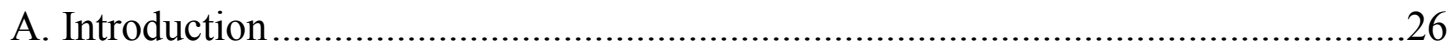

B. Determinants and Estimates of Labor and Goods Markets Flexibility ....................28

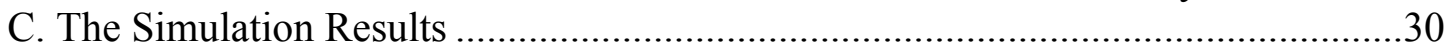

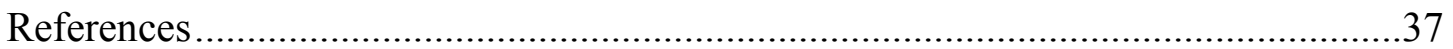

Figures

I.1. Net International Investment Position and Components, 2003 .....................................13

I.2. Net International Investment Position, 1996-2003 …….............................................14

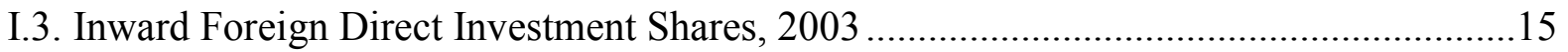

I.4. Investment, Saving and Current Account Ratios, and Growth........................................16

I.5. Structure of Financial Intermediaries, 1999-2003 ......................................................17

I.6. Enterprise and Household Financial Assets and Liabilities, 1996-2003 ..........................18

I.7. Private Sector Credit Developments, 2002-03 .............................................................19

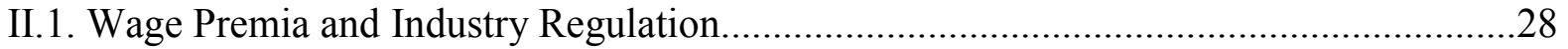

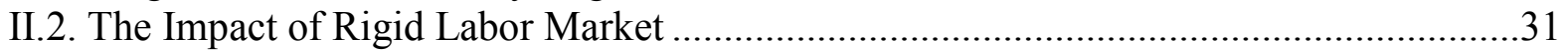

II.3. Increase of Markups in Tradables and Nontradables Goods Prices..................................32

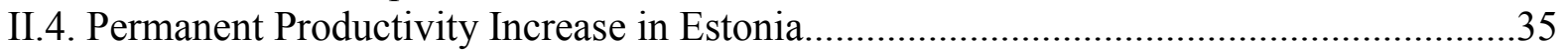

Tables

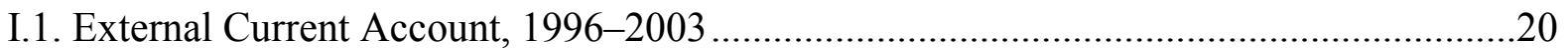

I.2. National Saving, Investment and Net Lending, 1993-2003 ..........................................21 
I.3. Household Disposable Income, Consumption and Saving, 1993-2003 ........................22

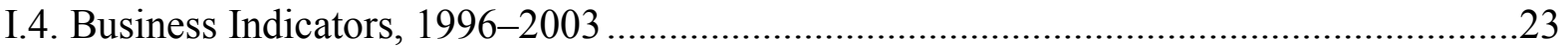

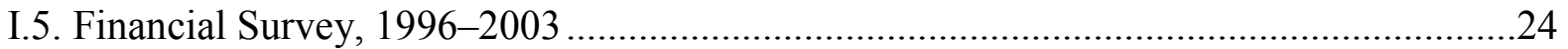

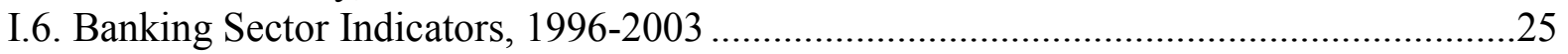

II.1. Average Markup Ratios by Market Structure Type .................................................29

II.2. Labor and Product Market Flexibility and Propagation of Shocks ..............................33

Appendices

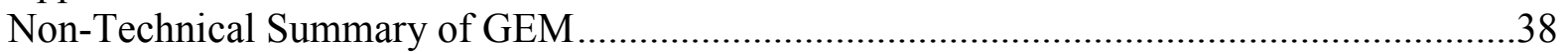

Appendix Tables

A1. Calibration of the Steady-State

Appendix Figures

A1. One Percentage Point Decline in the Euro Area Target Rate of Inflation

A2. One Percentage Point Increase in the EU Nominal Short-term Interest Rate.... 


\section{Estonia’s External Debt and Domestic Balance Sheet Developments ${ }^{1}$}

\section{A. Introduction}

1. Estonia's brisk growth has been associated with a rapid increase in its net external liabilities. Concerns have been expressed recently about the large external current account deficit, which exceeded 10 percent of GDP in 2002-03. However, a closer examination of the causes behind this deficit, including large "one-off" factors, and high imputed reinvested profits from foreign direct investments, as well as indications of continued strong external competitiveness, help to allay these concerns. Moreover, the method of financing the external deficit, relying largely on foreign direct investment and long-term debt, also reduces concerns about abrupt shifts in portfolio preferences by creditors.

2. The domestic counterparts to the external imbalances have been rising domestic investment levels and a worsening of households' net financial positions. Nonfinancial enterprise investments have increased as a share of output, as economic agents (both domestic and foreign) exploit profitable opportunities during the economy's rapid alignment with economic patterns observed in established European Union (EU) members, and employ its relatively inexpensive, but well educated labor force. Households, enjoying rapidly rising standards of living, and anticipating further increases to come, have increasingly turned to financial markets to finance new housing and consumer durables. However, despite annual private sector credit growth rates of 20-30 percent over the last five years, credit levels remain comparatively low. Moreover, the banking system remains robust, with enviably high profits and minimal bad loan burdens. Nevertheless, financial supervisors should remain vigilant, lest risks of financial accelerator effects manifest themselves, and thereby exacerbate the business cycle, although at present signs of this are, at best, limited.

3. This paper examines developments in Estonia's expanding net external obligations, as well as in domestic income flows and balance sheets. ${ }^{2}$ The next section discusses external current account and net international investment positions (NIIPs), while domestic investment, saving and balance sheet developments for the domestic sectors are covered in Section C. Section D concludes.

\section{B. Estonia's External Position}

4. Estonia has the highest negative NIIP among new EU members, and among the highest compared with EU members and other advanced economies (Figure I.1). At almost 70 percent of GDP, its net obligations are exceeded only by those in Iceland and New

\footnotetext{
${ }^{1}$ This paper was prepared by Mark Lutz.

${ }^{2}$ Similar reviews have also recently been undertaken for a number of other economies with large negative NIIP positions, including Australia, Iceland, and New Zealand.
} 
Zealand (both at about 75 percent of GDP). This is at first somewhat surprising and a potential source of concern. Given Estonia's significantly lower income level, its negative NIIP share may be expected to further worsen with a convergence of real incomes to EU averages. However, examining the components of Estonia's external investment position provides some comfort. The share of foreign direct investment (FDI), which is long-term in nature, and more flexible in its servicing requirements, is quite large, easily the largest as a share of GDP among new EU members. ${ }^{3}$

5. Estonia's gross external assets and liabilities have both increased in recent years, reflecting both growing economic and financial integration into the world economy (Figure I.2). Foreign assets have almost doubled as a share of GDP since 1996, from 30 percent to about 60 percent of GDP, while the share of foreign liabilities has almost tripled from roughly 45 percent of GDP in 1996 to about 125 percent in 2003 . As a result, the negative NIIP has increased from 14 percent of GDP to 69 percent over this period. The bulk of the change (45 percentage points of GDP) in the NIIP position was accounted for by increased foreign direct investment, reflecting the economy's solid external competitiveness. In addition, a sizable portion of "other investment" liabilities comprises loans by foreign parent banking companies to their Estonian firms which, according to the balance of payments methodology, are not included in foreign direct investments. ${ }^{4}$ Seventy percent of FDI inflows are from Sweden and Finland, with five other countries accounting for a further 15 percentage points of the total (Figure I.3). Foreign directed firms are found in most economic sectors, but are especially dominant among financial institutions, while major presences are also felt in manufacturing; transport, storage, and communications; and trade. ${ }^{5}$ Among foreign claims, reserve assets are sizable (equivalent to 14 percent of GDP in 2003), which provides the backing for the country's currency board arrangement. Estonia's foreign direct investment position abroad is surprisingly large, at 10 percent of GDP in 2003 (second only to Cyprus among new EU members, but lower than the 27 percent EU average) and expanding, mainly in their Baltic neighbors, with banking subsidiaries relatively important.

6. When Estonia's foreign asset and liability positions are examined by institutional sectors, the bulk of foreign assets are publicly owned, while most foreign

${ }^{3}$ FDI was equivalent to 64 percent GDP in 2003, and 50 percent of total external liabilities. The FDI shares were even larger in a number of other advanced economies (Belgium, 87 percent of GDP; Hong Kong SAR, 202 percent; Ireland, 136 percent; Malta, 70 percent; Netherlands, 76 percent; and Singapore, 167 percent).

${ }^{4}$ Republic of Estonia (2004), Annex 2, reports that of the EEK 7 billion increase in other investment liabilities in 2003, EEK 5.4 billion were loans and short-term deposits by foreign parents to domestic banking sector offspring.

${ }^{5}$ The Financial Supervisory Authority (FSA, 2004) reports that at the end of 2003 87.5 percent of banking sector share capital belonged to non-residents. 
liabilities are privately owed. The government has substantial net foreign assets, reflecting the authorities' history of prudent fiscal policy (domestic debt is also extremely low). The Bank of Estonia has sizable levels of other foreign claims in addition to official reserves. Banks have an increasingly negative net asset position, as they have relied to a greater extent in recent years on foreign funding (both from loans and deposits from their parent institutions, and by market-based borrowing) for their rapidly growing domestic lending portfolios. The other sector's net liability positions also has quickly risen, largely comprising foreign direct investment-related liabilities (see above), although a 15 percentage point of GDP increase in the market capitalization of the domestic stock market during 2001-03, about 80 percent of which is held by non-resident investors, also had an influence. ${ }^{6}$

7. The Estonian economy has been expanding rapidly, with per capita real incomes rising by 75 percent in the last decade. This was the result of high domestic investment rates, with the average investment share the highest among new EU members in recent years, and sizably above the shares in the old EU and in other large NIIP debtors, although recent shares have been temporarily inflated by a number of large, "one-off" projects (see below, and Figure I.4). The saving rate, in contrast, has been average compared to those in other new EU members, but higher than then those in other high net external liability economies.

\section{Although Estonia's export growth has been significant (with a doubling of} export market shares in recent years), and competitiveness remains strong, the current account deficit widened sizably in 2002-03 above 10 percent of GDP (Table I.1). This was, in part, attributed to "one-off" investments, whose direct external impact totaled 2.8 percentage points of GDP in 2002 and 4.6 percentage points of GDP in $2003 .{ }^{7}$ In addition, because of the sizable profits earned by the large stock of inward foreign direct investments, the vast bulk of these are reinvested, which are recorded as an outward payment in the current account, but as an offsetting inflow in the financial account, with no actual financial transactions taking place. ${ }^{8}$ Abstracting from these two influences, the "underlying" current account deficit has been much smaller in recent years, well below 5 percent of GDP.

\footnotetext{
${ }^{6}$ See Bank of Estonia (2004) for a brief description of stock market developments.

7 These projects are discussed in Republic of Estonia (2004), Annex 2, but are based on the yet-to-be-revised lower estimates for GDP, and thus contains higher shares of the size of the investments relative to the economy. These projects include modernizing the domestic power system, requiring investment goods and construction services imports. In addition, a large number of railway oil tankers were imported, to be leased to Russian companies. While the former project will have an only indirect benefit to exports in the future, the latter will immediately increase leasing services receipts.

${ }^{8}$ The share of FDI earnings reinvested in Estonia averaged 63 percent during 1996-2003, rising to 79 percent in 2003.
} 
9. The large external imbalances have been overwhelmingly financed with "cold money." FDI inflows has offset the vast bulk of the current account deficit (equivalent to 70 percent on average during 1996-2003). Other investments have played an increasing role in the last two years, although as mentioned above a large part of this is disguised FDI, supplemented by market-based borrowing by the banking sector. The government and nonfinancial enterprise sectors have been largely absent from international financial markets.

\section{Domestic Investment, Saving, and Balance Sheet Developments}

10. The widening external current account deficit reflects increasing divergences between national saving and investment (Table I.2). The investment share, as discussed above, has recently been boosted by large "one-off" projects, but remains comparatively high abstracting from them. The national saving rate has been broadly constant over the last decade, but its composition has changed somewhat. The GDP-based gross household saving rate (including depreciation) fell significantly in 2002, while the general government saving rate has increased sizably since the economic downturn in 1999. Nonfinancial enterprise saving has also been strong in recent years.

11. Explaining the decline in the household saving rate is somewhat complex. The saving rate was relatively constant as a share of disposable income until 2002, when it plunged sharply, reflecting a surge in consumption (Table I.3). When expressed as a share of GDP however, the increase in the consumption share, and the drop in the saving rate, was less pronounced. ${ }^{9}$ This results from the fact that disposable income itself has declined as a share of GDP by $23 / 4$ percentage points in the last five years, a reflection in part of employees' compensation decline as a share of GDP (which is turn helped boost enterprise saving). In addition, reform of the Estonian public pension system resulted in 2002 in over 200,000 individuals (about 35 percent of eligible employees) joining a voluntary second pillar pension system, with a newly introduced 2 percentage point of wages contribution paid by workers. However, from a national income accounting position, these contributions, equivalent to $1 / 2$ percentage point of GDP, are included among current taxes paid, thereby overstating the decline in actual saving from the households' perspective. ${ }^{10}$ The staff estimates that, largely on the basis of slight increase in the share of employee compensation and reversal in the private consumption share, the household saving rate rebounded somewhat in 2003.

\footnotetext{
${ }^{9}$ The net saving rate, expressed as a share of GDP in the bottom of Table 3, differs from gross saving data in Table 2 by household consumption of fixed capital, which also has declined by about 1 percentage point of GDP over 1998-2003.

10 This, of course, improves the general government saving rate by the same amount, while leaving the national rate unaffected.
} 
12. Estonia's domestic financial system remains largely dominated by banks, but other institutions are growing rapidly. Banks' domestic credit (excluding loans to other financial institutions - mainly leasing companies) remains by far the largest source of domestic financing, equivalent to almost two-thirds of GDP in 2003 (Figure I.5). The stock market's recent bullish behavior has boosted market capitalization to 40 percent of GDP, and by a further 8 percentage points in the first quarter of this year, but four-fifths of this is foreign owned. Leasing activities (for real estate, autos, commercial vehicles, and other items, provided by institutions almost wholly owned by Estonian banks), are unusually prominent in Estonia, and have grown rapidly in recent years. The bond market remains relatively dormant, and insurance premiums grew only somewhat faster than the overall economy. The assets of investment funds (again, largely owned by domestic banks), in contrast, while still relatively small, are surging, in part reflecting the creation of a fullyfunded second pension pillar. ${ }^{11}$

\section{As is traditional in other economies, Estonian nonfinancial enterprises are net}

financial debtors. Expressed as a share of their value added, enterprise net debt has been broadly stable in recent years (Figure I.6). Although still dominant, bank loans have declined in relative importance, with a shift to leasing as a source for financing physical assets. Banking sector loans were overwhelmingly (over 80 percent) denominated in foreign currencies, almost exclusively (about 95 percent) in euros, which until recently carried interest rates lower than those denominated in local currencies. ${ }^{12}$ Over 80 percent of total loans were long term, with maturities of 5-10 years accounting for more than half of total loans.

\section{The overall debt-equity ratio among nonfinancial firms has been stable}

(Table I.4). In comparison with other economies with large negative NIIP positions, leverage ratios are lower than in Iceland (about 200 percent), on par with those in Australia, and higher than in New Zealand (about 40 percent). Using a micro dataset which tends to represent larger enterprises, Nivorozhkin (2004) finds average leverage was at levels comparable to that in the Czech Republic (and comparable to the levels in Table I.4), while higher than in Poland, Romania, and Bulgaria. He found that firm leverage was positively related to the degree of banking sector privatization, and higher growth, while higher foreign direct investment was associated with lower leverage. On balance, he found that enterprise leverage in Estonia was below its expected levels, as in the Czech Republic, but in contrast to higher than predicted leverage in Bulgaria, Poland, and Romania.

${ }^{11}$ Third pillar, voluntary, pension savings are also beginning to emerge, but totaled only about $1 / 2$ percent of GDP at the end of 2003.

${ }^{12}$ Data are not available on the degree to which enterprises are either naturally hedged or hedge themselves through financial markets, although the latter is thought to be rather small. 


\section{Various other business indicators suggest that Estonian enterprises are quite} profitable. The return on equity, return on assets, and total profit to net sales ratios have all been quite solid since the post-Russian crisis induced downturn in 1999. Manufacturing returns, which tends to be more tradable on average than the overall economy, is slightly more profitable, but also more volatile. This in part reflects greater productivity gains in manufacturing in recent years, with similar increases in real wages as in other economic sectors, suggesting a better unit labor cost performance.

\section{In contrast, households' net financial assets position has worsened significantly} in the last two years. The net asset ratio stood at $11 \frac{1}{2}$ percent of disposable income in 2000 , but declined to a $-2^{1 / 2}$ percent in 2003 . This is consistent with the declining household saving rate, but for a similar reason may be overstated, as pillars II and III investment fund assets, which remain small, and for data limitations reasons are not included here, have grown recently. Nevertheless, the declining saving rate, and financial position are consistent with findings that the current account has been boosted in part for consumption smoothing reasons (IMF, 2003).

\section{After growing rapidly in the late 1990s, household deposits have stabilized as a} share of disposable income, while borrowing has increased sharply. The slowing growth of household deposits is thought to be affected by low interest rates, and to some degree the creation of alternate second pillar saving vehicles. Borrowing has been predominately for mortgages and auto loans (the latter largely through leasing companies). Borrowing also has been largely in foreign currencies, but, at two-thirds of total household borrowing, is lower than for nonfinancial enterprises (although households also have fewer opportunities for hedging). Over ninety percent of all household lending has been long-term since 1997, with about one-third for more than 10 years maturity. Mortgage lending is overwhelmingly done with floating rates.

\section{Debt servicing costs remain low; this reflects both low interest rates and a low} share of households that have loans. Interest payments totaled only 2 percent of disposable income in 2002, although this reflects both still immature financial deepening (see below) and cyclically low interest rates. Based on aggregate banking statistics and macroeconomic indicators, the Bank of Estonia (2004) estimated that total debt servicing costs (including principal repayment) totaled more than 12 percent of households' disposable income in that year. This figure is also low from an international perspective, but reflects in part that only 10-15 percent of households have mortgages. Given the predominance of variable rate lending, there are risks that rising future interest rates, if combined with a slowdown in the economic cycle and higher unemployment, could pose some tensions in debt servicing. ${ }^{13}$

\footnotetext{
${ }^{13}$ While the aggregate debt servicing ratio remains comfortable, this may mask some individual pressures. The Bank of Estonia (2004) cited a recent survey in which 68 percent of respondents considered their loan servicing costs to be low or reasonable, but over 10 percent of families stated their burdens exceeded more than 30 percent of their net incomes.
} 
19. The pace at which financial deepening has progressed, especially regarding bank lending, is remarkable, and with increasing reliance on foreign funding. Domestic credit by the banking and leasing systems has increased dramatically since the mid-1990s (Table I.5). The government, in contrast to many other transition and advancing economies, remains a net bank creditor. Private sector credit has more than doubled as a share of GDP since 1996, and totaled about 50 percent of GDP in 2003. While the growth of credit to enterprises has remained, at 15-20 percent per annum in recent years, relatively moderate, credit growth to households has exceeded 40 percent every year since 2000, with the stock of credit as a share of GDP almost tripling. In contrast, the growth of broad money has slowed to 11 percent on average the last two years, about the same pace as in the overall economy. Already in 2002, the stock of credit to the private sector exceeded broad money. As a result, banks have increasingly relied on foreign funding for its burgeoning loan portfolios, to the point that the net foreign asset position of the financial system turned negative in 2003 . Helped by increased ratings by foreign agencies, one bank began a successful short-term Eurobonds issue in December, 2003, building on a long-term issue from the previous March. Nevertheless, as of March 2004, 45 percent of external loans had been obtained from parent banks (Bank of Estonia, 2004). Banks rely on short-term deposits from their parents as well.

20. Despite its rapid growth, the private sector credit stock remains comparatively modest as a share of GDP from an international context, and its growth is in line with experiences in other economies in similar circumstances. It is well known that financial market deepening is positively related with economic development (proxied by per capita GDP, Figure I.7). When viewed in this context, neither the Estonian private sector nor household credit stocks (including or excluding leasing credit) appear to be outliers. While slightly higher than in other Baltic or Central European economies, the shares in Malta and Cyprus are higher, and somewhat higher in Slovenia. In addition, Estonia's high credit growth rates are also broadly in line with expectations, given the negative relationship between growth and the outstanding stock.

21. The Estonian banking sector is financially sound, comparatively efficient, and highly profitable. Its weighted-average capital adequacy ratio easily exceeds the nationally determined 10 percent minimum, and well above the Basel 8 percent minimum (Table I.6). Its non-performing loan ratio is enviable, although it has yet to be tested by a sustained economic downturn. ${ }^{14}$ (and financial accelerator effects may emerge, but are at best nascent). Increasing bank competition has cut the net interest margin, but higher loan volumes, increasing banking fees and other income have more than offset this, bolstering banking profitability. These patterns are consistent with recent research by Bonin, Hasan, and Wachtel (2004a, 2004b), who found that in the late 1990s-early 2000s in transition economies, banking sector efficiency and profitability was enhanced by foreign ownership,

14 The nonperforming loan ratio rose in 1999, following the Russian crises and a sharp fall of domestic demand. This resulted in a reduction of the capital adequacy ratio in 2000, with a writing off of bad debt, also cutting profits in that year. 
especially by strategic investors. This is consistent with the idea that these investors transfer also technology and know-how to their offspring.

\section{Banking penetration, especially for mortgages, remains somewhat}

underdeveloped. While 10-15 percent of households presently have mortgages, some banking sector participants estimated that the share of households that would presently be financially eligible totaled some 15-20 percent, and this was increasing over time. Other participants expected the market for this product to be largely saturated by 2006 . Unsecured consumer credit also remains relatively underdeveloped.

\section{Nevertheless, rapid credit growth combined with excessive consumer and} business confidence could set the stage for financial excesses, although this does not presently appear to be the case. Banks are reported (by themselves and supervisors) to be conservatively implementing their credit scoring rules and lending decisions, employing systems developed by their parent banks, who in turn remember well mistakes made in the Nordic economies' bubble/collapse in the early 1990s. The share of collateralized lending (especially mortgages) has grown, and lending ratios are considered prudent. ${ }^{15}$ Banks also implement quarterly stress tests on their portfolios, using models developed by their parent banks, while financial supervisors replicate these results and undertake their own simulations. Supervisors have also instructed banks to educate their potential customers about the implications of likely future increases in interest rates for debt servicing obligations. Nevertheless, experiences in other economies warn of the risk of financial acceleration exacerbating business cycles. ${ }^{16}$ However, most macroeconomic indicators (including inflation, wage growth, the unemployment rate, and consumer confidence) suggest that these risks are largely minimal. One exception may relate to housing, where flat prices in the capital and two other large cities have increased substantially in recent years. ${ }^{17}$ Thus, it remains incumbent upon financial supervisors to remain vigilant to emerging pressures.

\footnotetext{
${ }^{15}$ Mortgage lending was generally limited to 70 percent of sale prices. However, guarantees provided by Kredex, a quasi-government agency providing assistance to families, young professionals, and tenants renovating large apartment blocks, allow for higher credit limits, and cover 16 percent of existing mortgage credit at the end of 2003, and about 20 percent of new loans granted.

${ }^{16}$ See Borio, Furfine, and Lowe (2000) for a good discussion of financial accelerator risks, and alternate supervisory approaches.

17 Two-bedroom flat prices have doubled in Tallinn since 1997, while three bedroom flat prices increased by two-thirds; prices in two other large cities increased by up to three times over this period. However, the extent to which this reflects national patterns, and the statistical reliability of the data, especially taking account of improved housing quality, may reduce concerns about these developments.
} 


\section{Summary and Conclusions}

24. The Estonian economy's rapid economic growth has benefited from access to international goods and capital markets, although this has resulted in a sizably negative net international investment position. This pattern is not at all unusual at this stage of the development process, and enhances social welfare. The rapid increase in economic convergence has been based on the economy's well educated and flexible labor force, and complemented by the transfer of external capital and technology. As a share of the economy, foreign direct investment flows have been the largest among new EU entrants, which, while imposing future servicing obligations, tends to be more stable and flexible than other forms of external financing.

25. A counterpart to these external flows has been a large increase in the domestic credit ratios, although they are not outliers from an international perspective. Enterprise profitability remains robust, bolstered by wage restraint, while household net saving has deteriorated sizably in recent years. This reflects access to mortgages and other lending vehicles, which are yet to be fully exploited. Despite rapid increases in credit ratios, they remain well within historical experiences of other economies at this stage of development.

26. While financial sector practices appear to be prudent, vigilance remains the watchword to ensure against nascent imbalances. Banks have adopted their parents' internal prudential controls, informed by hard lessons learned in earlier Nordic financial sector difficulties. While financial accelerator effects remain a risk to the present economic upturn, most macroeconomic indicators, with the exception of flat prices, suggest that a bubble is not yet a concern. Nevertheless, close monitoring of developments is essential. 


\section{References}

Bank of Estonia (2003), "Financial Stability Review: November 2003,” Tallinn, November.

Bank of Estonia (2004), "Financial Stability Review: May 2004,” Tallinn, May.

Bonin, John P., Iftekhar Hasan, and Paul Wachtel (2004), "Bank Performance, Efficiency and Ownership in Transition Countries," Bank of Finland BOFIT Discussion Papers, 2004 No. 7, Helsinki.

Bonin, John P., Iftekhar Hasan, and Paul Wachtel (2004), "Privatization Matters: Bank Efficiency in Transition Countries," Bank of Finland BOFIT Discussion Papers, 2004 No. 8, Helsinki.

Borio, Claudio, Craig Furfine, and Phillip Lowe (2000), "Procyclicality of the Financial System and Financial Stability: Issues and Policy Options," BIS Conference Papers No. 8, International Financial Markets and the Implications for Monetary and Financial Stability, Basle, March.

Financial Supervisory Authority (2004), "Yearbook: 2003," Tallinn.

International Monetary Fund (2003), IMF Country Report No. 03/331, Washington, October.

Nivorozhkin, Eugene (2004), "Financing Choices of Firms in EU Accession Countries," Bank of Finland BOFIT Discussion Papers, 2004 No. 6, Helsinki.

Republic of Estonia (2004), “Convergence Programme: 2004,” Tallinn, May 13, 2004. 
Figure I.1. Estonia: Net International Investment Position and Components, 2003 1/ (Percent of GDP)
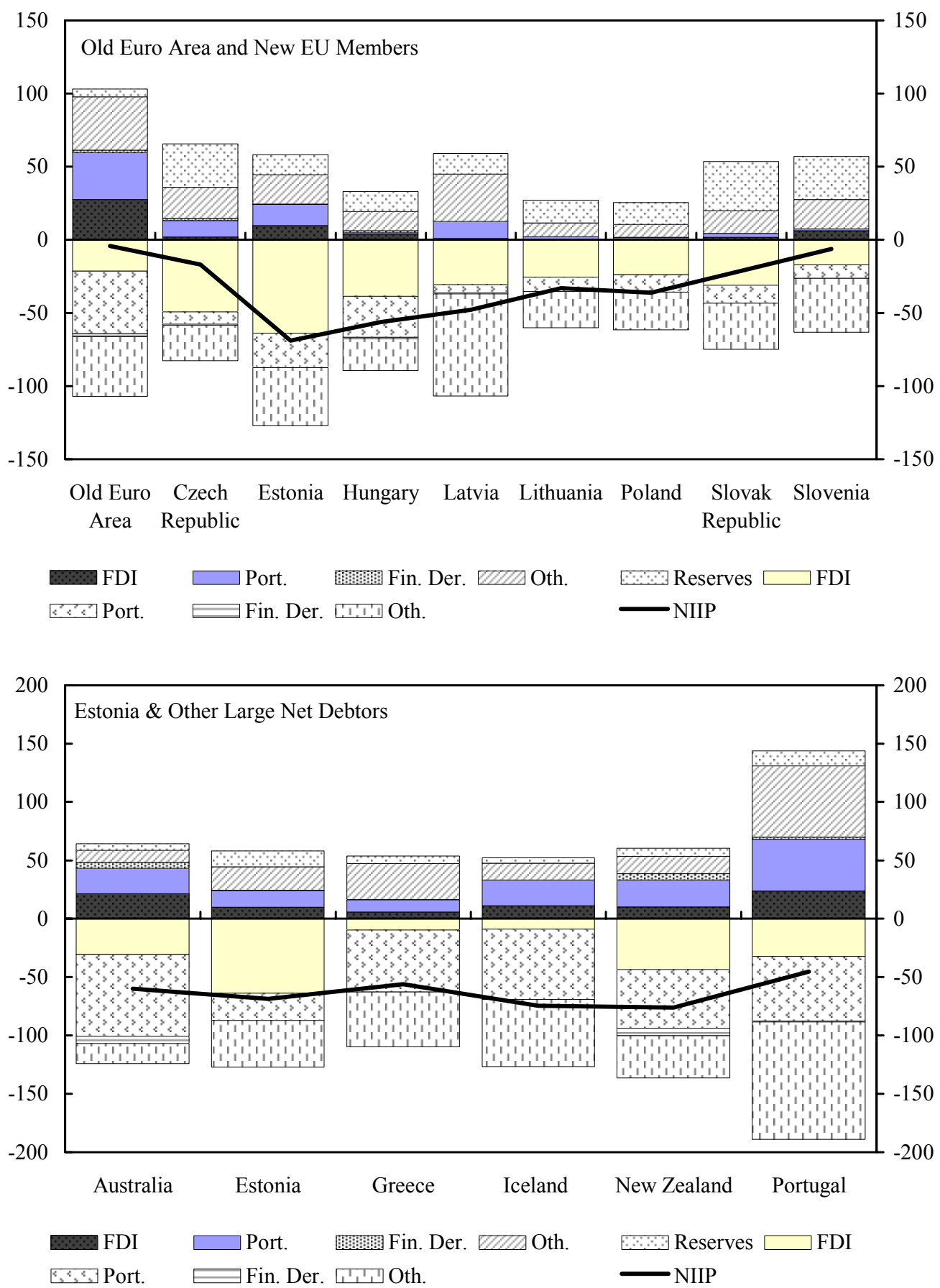

Sources: International Financial Statistics Database; and staff calculations.

1/ Data for the old Euro area, Hungary, Lithuania, Poland, Slovak Republic, Slovenia, Greece, Iceland, and Portugal are for 2002. 
Figure I.2. Estonia: Net International Investment Position, 1996-2003 (Percent in GDP)
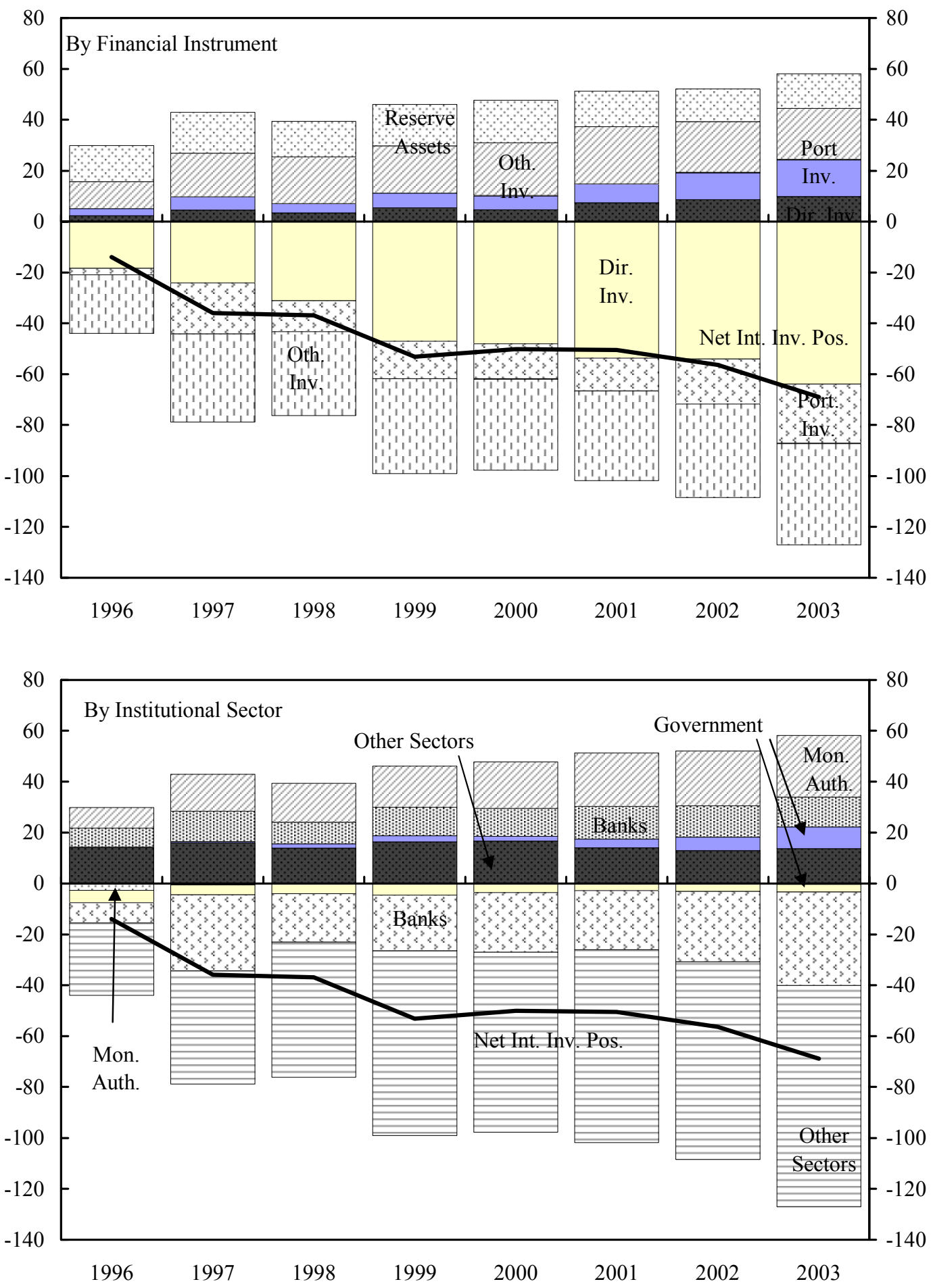

Sources: Estonian authorites; and staff calculations. 
Figure I.3. Estonia: Inward Foreign Direct Investment Shares, 2003
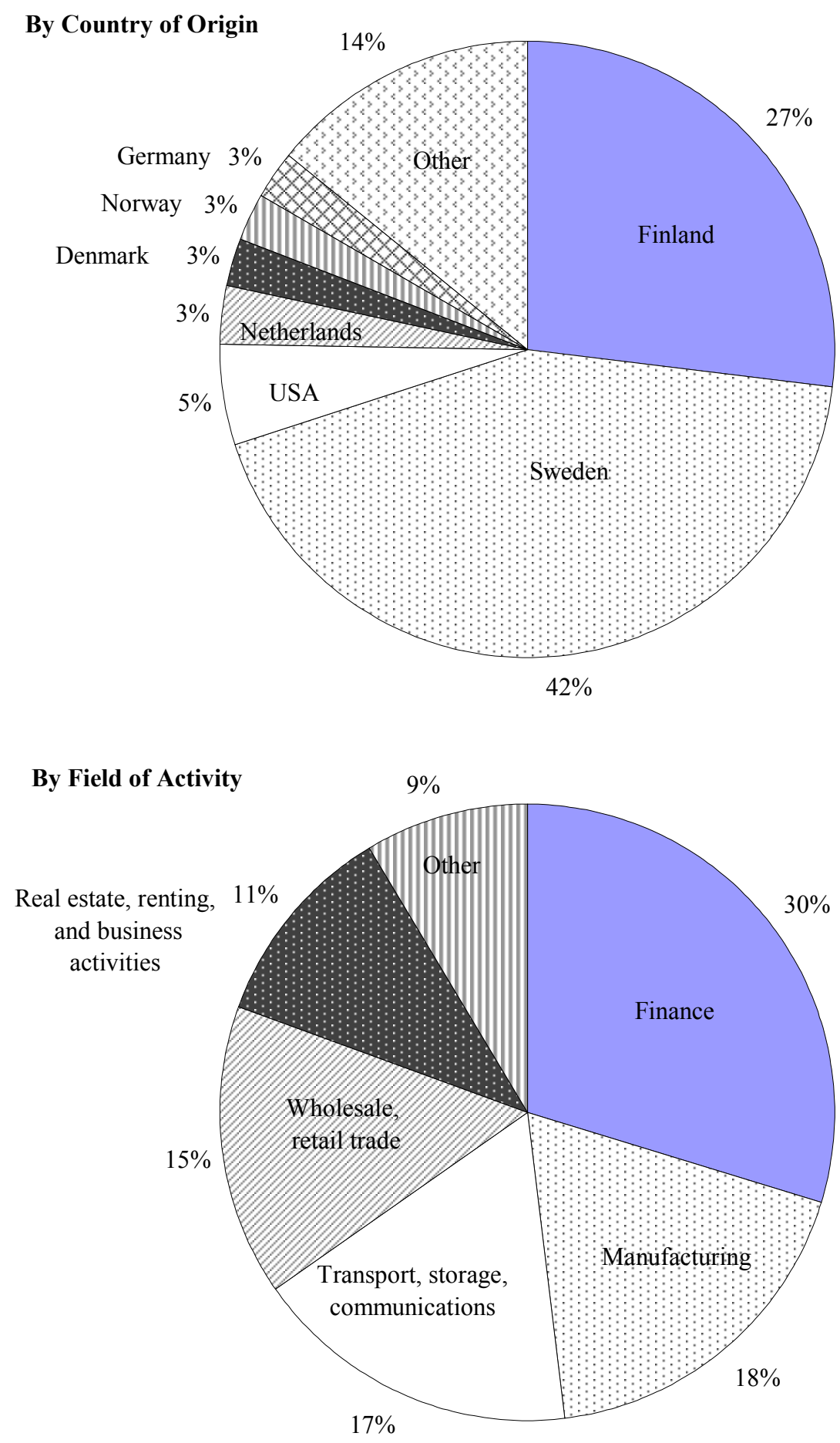

Sources: Bank of Estonia; and staff calculations. 
Figure I.4. Estonia: Investment, Saving and Current Account Ratios, and Growth (2001-03 Averages) 1/

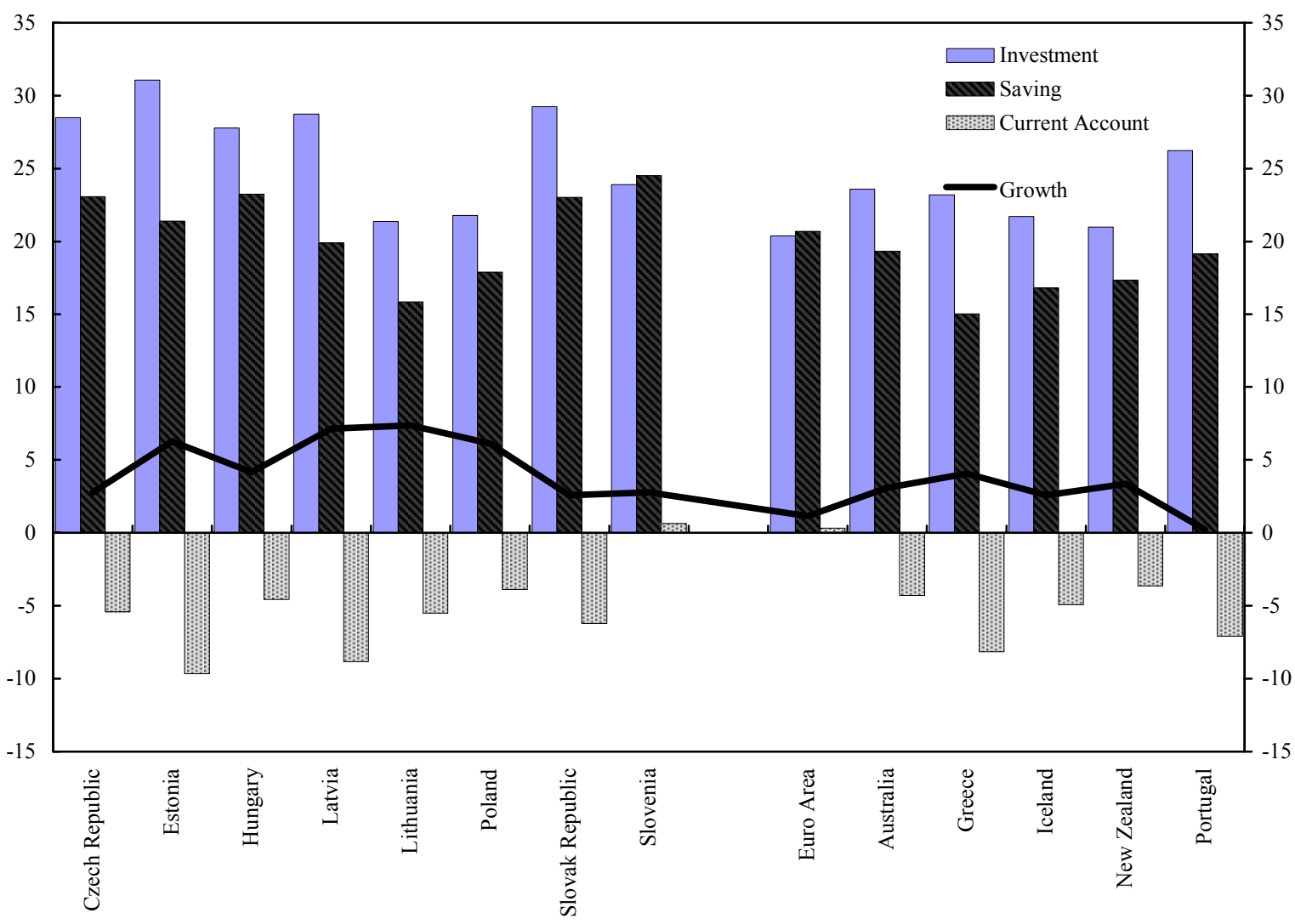

Sources: IFS database; Statistical Office of Estonia; and staff calculations.

1/ Data for Czech Republic, Hungary, Poland, Greece and Iceland are from 2000-02, and for Slovak Republic for $1998-2000$. 
Figure I.5. Estonia: Structure of Financial Intermediaries, 1999-2003 (Percent of GDP)

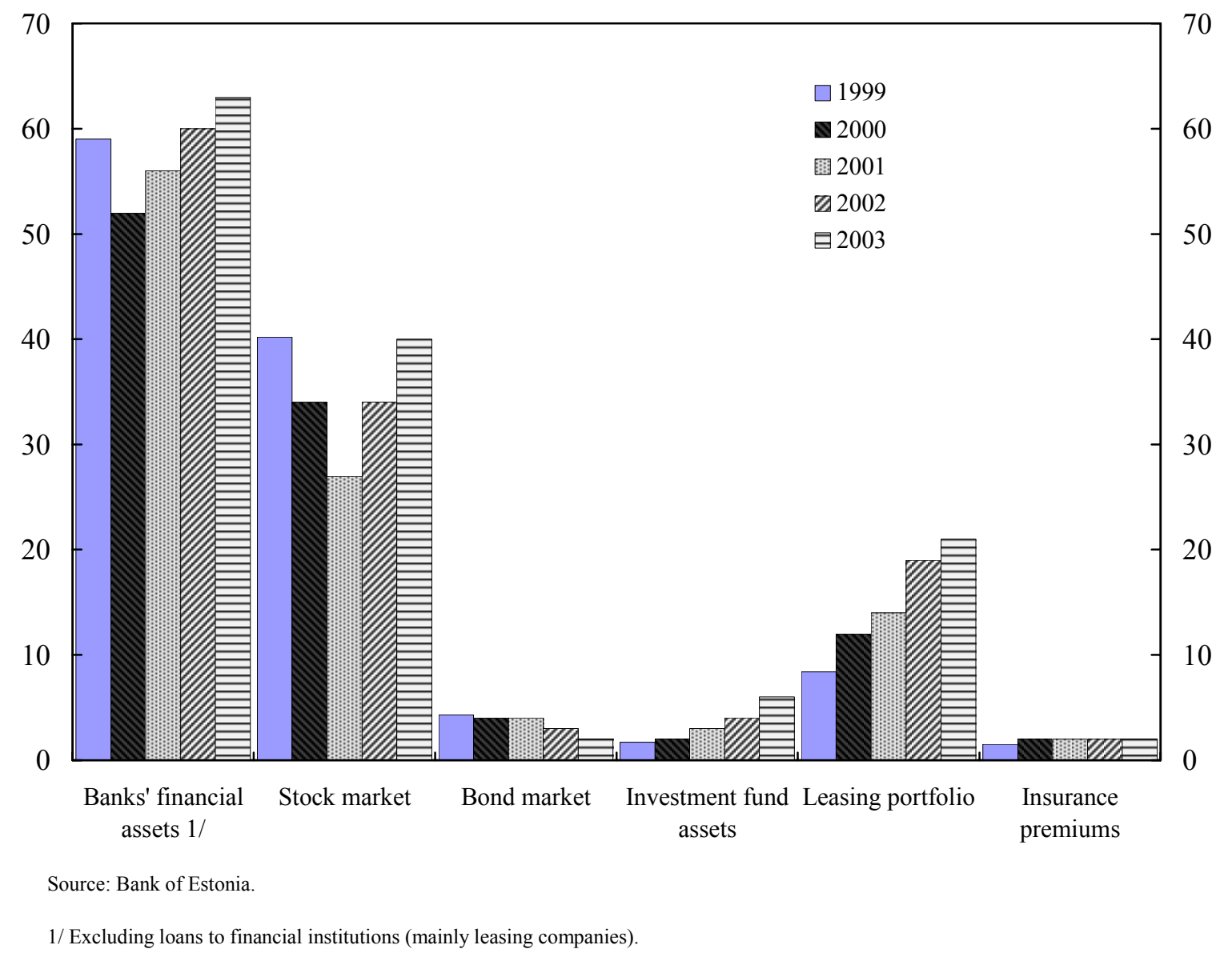


Figure I.6. Estonia: Enterprise and Household Financial Assets and Liabilities, 1996-2003 (Share of Enterprise Value Added/Household Disposable Income) 1/
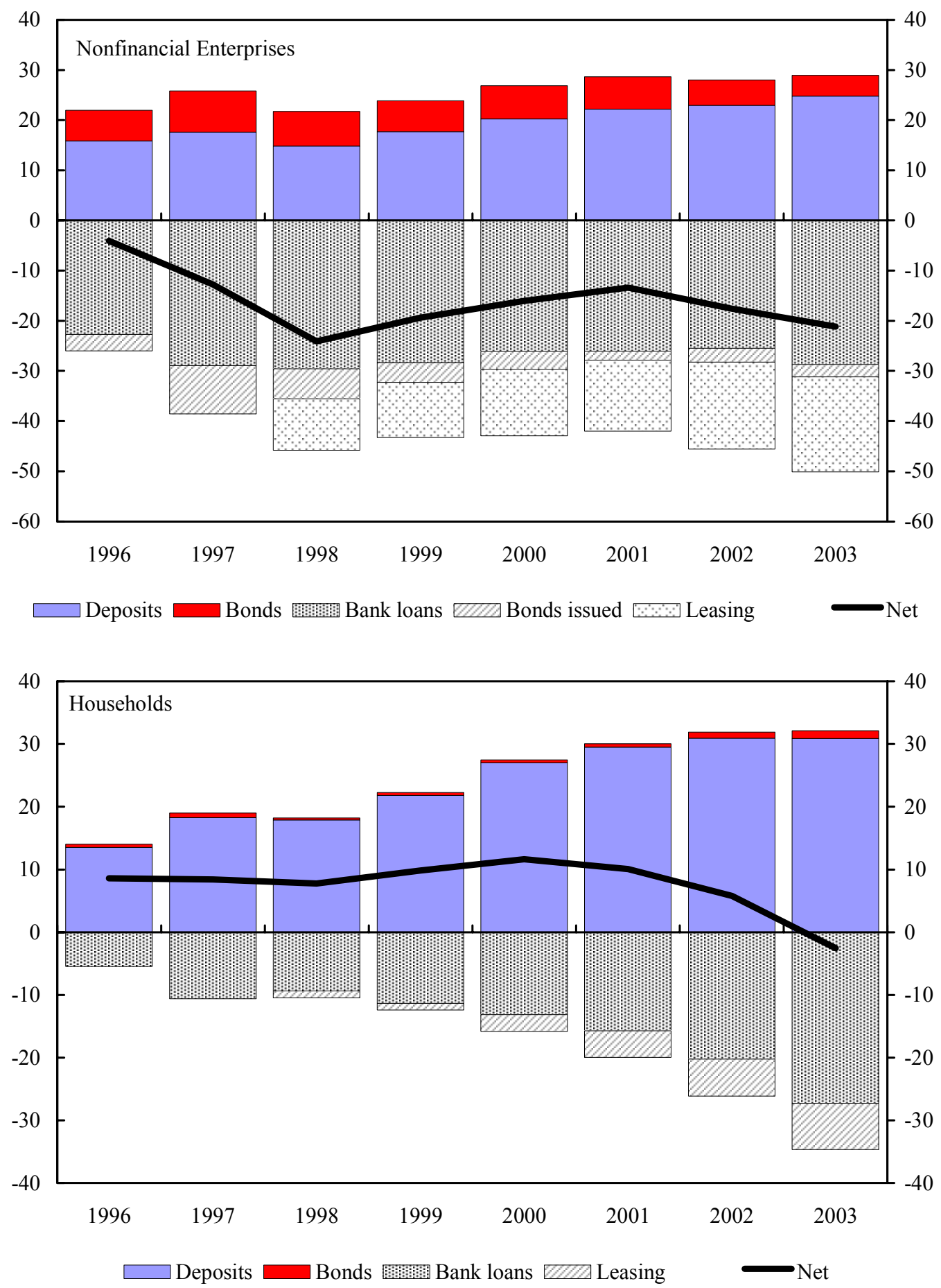

Sources: Bank of Estonia; and staff calculations.

1/ Staff estimates for 2003 household disposable income. 
Figure I.7. Estonia: Private Sector Credit Developments, 2002-03
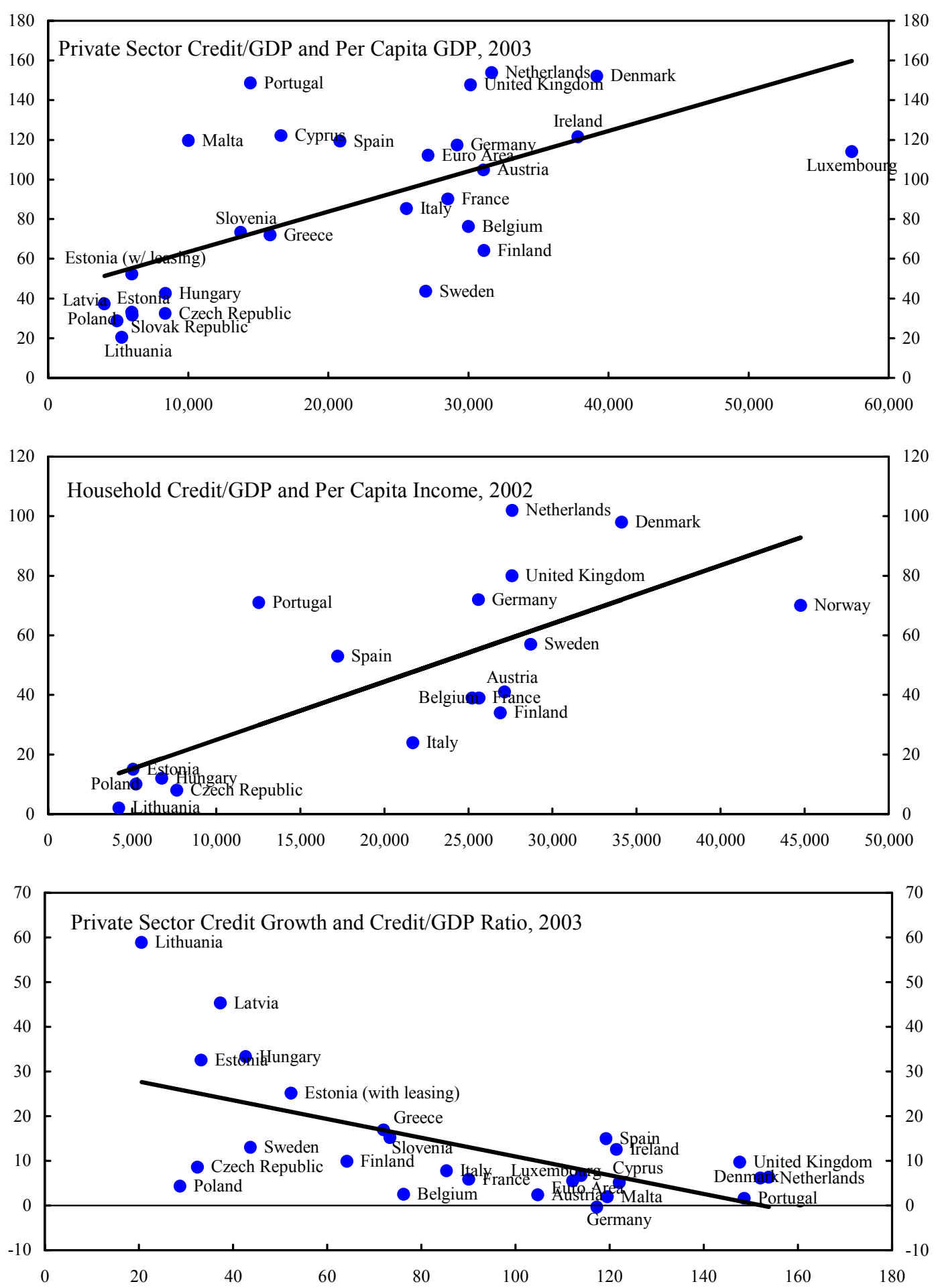

Sources: IFS database; Bank of Estonia; Statistical Office of Estonia; and staff calculations. 
Table I.1. Estonia: External Current Account, 1996-2003

(Percent of GDP)

\begin{tabular}{|c|c|c|c|c|c|c|c|c|}
\hline & 1996 & 1997 & 1998 & 1999 & 2000 & 2001 & 2002 & 2003 \\
\hline Current account & -8.6 & -11.4 & -8.6 & -4.4 & -5.5 & -5.6 & -10.2 & -13.2 \\
\hline Reinvested earnings & -0.4 & -1.9 & -0.5 & -0.9 & -2.0 & -3.7 & -2.9 & -5.3 \\
\hline Other & -8.2 & -9.5 & -8.1 & -3.5 & -3.5 & -1.9 & -7.3 & -7.8 \\
\hline Capital account & 0.0 & 0.0 & 0.0 & 0.0 & 0.3 & 0.1 & 0.3 & 0.4 \\
\hline Financial account & 11.4 & 16.0 & 8.7 & 7.2 & 5.1 & 5.3 & 9.8 & 12.8 \\
\hline Foreign direct investment & 2.4 & 2.6 & 10.2 & 3.9 & 6.0 & 5.7 & 2.2 & 8.3 \\
\hline Reinvested earnings & 0.4 & 1.9 & 0.5 & 0.9 & 2.0 & 3.7 & 2.9 & 5.3 \\
\hline Other FDI & 2.0 & 0.7 & 9.7 & 3.0 & 4.1 & 1.9 & -0.6 & 3.0 \\
\hline Portfolio investment & 3.2 & 5.3 & 0.0 & 0.2 & 1.5 & -0.6 & 2.1 & 1.9 \\
\hline Equity & 3.4 & 0.8 & 1.2 & 4.3 & -0.5 & 0.8 & 0.8 & 0.4 \\
\hline Other & -0.2 & 4.6 & -1.2 & -4.1 & 2.1 & -1.4 & 1.3 & 1.5 \\
\hline Financial derivatives & $\ldots$ & $\ldots$ & $\ldots$ & $\ldots$ & 0.0 & 0.0 & -0.1 & 0.0 \\
\hline Other investment & 5.9 & 8.1 & -1.4 & 3.1 & 0.0 & -0.4 & 6.4 & 4.5 \\
\hline Reserve assets & -2.2 & -4.1 & -0.2 & -2.2 & -2.4 & 0.7 & -0.8 & -1.8 \\
\hline Errors and omissions & -0.6 & -0.5 & 0.0 & -0.6 & 0.1 & 0.3 & 0.1 & -0.1 \\
\hline $\begin{array}{l}\text { Memorandum items: } \\
\text { Impact of "one-off" }\end{array}$ & & & & & & & & \\
\hline investments on CA balance & $\cdots$ & $\cdots$ & $\cdots$ & $\cdots$ & $\cdots$ & $\cdots$ & 2.8 & 4.6 \\
\hline $\begin{array}{l}\text { CA balance, net of "one-off" } \\
\text { investments and reiv. earn. }\end{array}$ & -8.2 & -9.5 & -8.1 & -3.5 & -3.5 & -1.9 & -4.5 & -3.2 \\
\hline FDI/CA balance (percent) & 27.7 & 22.8 & 118.2 & 88.9 & 110.0 & 100.2 & 22.0 & 63.0 \\
\hline
\end{tabular}

Sources: Bank of Estonia; Statistical Office of Estonia; and staff calculations. 
Table I.2. Estonia: National Saving, Investment and Net Lending, 1993-2003 (Percent of GDP)

\begin{tabular}{|c|c|c|c|c|c|c|c|c|c|c|c|}
\hline & 1993 & 1994 & 1995 & 1996 & 1997 & 1998 & 1999 & 2000 & 2001 & 2002 & $20031 /$ \\
\hline Gross Saving & 26.5 & 27.1 & 25.1 & 27.0 & 30.5 & 30.6 & 25.4 & 27.8 & 28.2 & 31.5 & 32.3 \\
\hline National & 27.7 & 20.2 & 20.9 & 18.4 & 19.1 & 22.0 & 20.9 & 22.4 & 22.6 & 21.3 & 19.1 \\
\hline General Government & 15.2 & 11.7 & 7.1 & 4.6 & 7.5 & 6.0 & 3.6 & 4.7 & 5.9 & 7.2 & 6.0 \\
\hline Financial Enterprises & 2.0 & 1.4 & 2.4 & 3.2 & 1.3 & 4.0 & 3.3 & 2.0 & 1.1 & 2.2 & $\ldots$ \\
\hline Nonfinancial Enterprises & 5.3 & 2.3 & 6.8 & 5.9 & 6.2 & 6.9 & 8.6 & 10.7 & 10.8 & 9.7 & $\ldots$ \\
\hline Households & 4.8 & 4.3 & 4.1 & 4.3 & 3.6 & 4.7 & 5.0 & 4.5 & 4.4 & 1.9 & $\ldots$ \\
\hline Nonprofits Serving Households & 0.4 & 0.5 & 0.5 & 0.5 & 0.5 & 0.4 & 0.4 & 0.5 & 0.4 & 0.2 & $\ldots$ \\
\hline Foreign & -1.2 & 6.8 & 4.2 & 8.6 & 11.4 & 8.6 & 4.4 & 5.5 & 5.6 & 10.2 & 13.2 \\
\hline Total Investment & 26.5 & 27.1 & 25.1 & 27.0 & 30.5 & 30.6 & 25.4 & 27.8 & 28.2 & 32.6 & 32.3 \\
\hline Gross fixed capital formation & 23.7 & 26.5 & 25.9 & 26.0 & 27.8 & 29.8 & 24.8 & 25.6 & 27.0 & 28.7 & 28.4 \\
\hline General government & 4.5 & 5.2 & 5.0 & 4.5 & 4.3 & 4.7 & 4.2 & 3.9 & 4.1 & 4.7 & 3.1 \\
\hline Financial Enterprises & 0.8 & 1.3 & 1.4 & 1.3 & 1.2 & 0.8 & 0.6 & 0.4 & 0.4 & 0.3 & $\ldots$ \\
\hline Nonfinancial Enterprises & 15.6 & 17.3 & 16.8 & 17.0 & 18.6 & 20.9 & 16.8 & 17.7 & 18.7 & 19.8 & $\ldots$ \\
\hline Households & 2.7 & 2.5 & 2.6 & 3.1 & 3.6 & 3.3 & 3.0 & 3.5 & 3.7 & 3.8 & $\ldots$ \\
\hline Nonprofits Serving Households & 0.1 & 0.1 & 0.1 & 0.1 & 0.1 & 0.1 & 0.1 & 0.1 & 0.1 & 0.1 & $\ldots$ \\
\hline Change in stocks $1 /$ & 2.8 & 0.6 & -0.8 & 1.0 & 2.7 & 0.8 & 0.6 & 2.2 & 1.3 & 3.9 & 3.9 \\
\hline \multicolumn{12}{|l|}{ Net Saving } \\
\hline National & 1.2 & -6.8 & -4.2 & -8.6 & -11.4 & -8.6 & -4.4 & -5.5 & -5.6 & -11.3 & -13.2 \\
\hline General government & 10.8 & 6.6 & 2.1 & 0.1 & 3.2 & 1.3 & -0.6 & 0.8 & 1.8 & 2.6 & 3.0 \\
\hline Financial Enterprises & 1.3 & 0.1 & 1.0 & 1.9 & 0.1 & 3.2 & 2.6 & 1.6 & 0.7 & 1.9 & $\ldots$ \\
\hline Nonfinancial Enterprises 2/3/ & -13.2 & -15.6 & -9.2 & -12.2 & -15.1 & -14.8 & -8.7 & -9.3 & -9.1 & -14.0 & $\ldots$ \\
\hline Households & 2.0 & 1.8 & 1.6 & 1.2 & 0.0 & 1.3 & 2.0 & 1.0 & 0.7 & -1.9 & $\ldots$ \\
\hline Nonprofits Serving Households & 0.3 & 0.3 & 0.3 & 0.4 & 0.4 & 0.3 & 0.3 & 0.4 & 0.3 & 0.1 & $\ldots$ \\
\hline Foreign & -1.2 & 6.8 & 4.2 & 8.6 & 11.4 & 8.6 & 4.4 & 5.5 & 5.6 & 10.2 & 13.2 \\
\hline \multicolumn{12}{|l|}{ Net Capital Transfers Received } \\
\hline National & 0.0 & 0.0 & 0.0 & 0.0 & 0.0 & 0.0 & 0.0 & 0.3 & 0.1 & 0.3 & 0.4 \\
\hline General government & 0.1 & -1.8 & -1.7 & -1.9 & -1.5 & -1.7 & -3.1 & -1.1 & -1.5 & -0.9 & -0.5 \\
\hline Financial Enterprises & 0.0 & 0.0 & 0.0 & 0.0 & 0.0 & 0.0 & 0.4 & 0.0 & 0.0 & 0.0 & $\ldots$ \\
\hline Nonfinancial Enterprises & -0.1 & 0.0 & 0.0 & 0.2 & 0.2 & 0.5 & 1.0 & 0.4 & 0.5 & 0.6 & $\ldots$ \\
\hline Households & 0.0 & 1.8 & 1.7 & 1.7 & 1.3 & 1.3 & 1.4 & 0.9 & 1.1 & 0.6 & $\ldots$ \\
\hline Nonprofits Serving Households & 0.0 & 0.0 & 0.0 & 0.0 & 0.0 & 0.0 & 0.3 & 0.1 & 0.0 & 0.0 & $\ldots$ \\
\hline Foreign & 0.0 & 0.0 & 0.0 & 0.0 & 0.0 & 0.0 & 0.0 & -0.3 & -0.1 & -0.3 & -0.4 \\
\hline \multicolumn{12}{|l|}{ Net lending (share of GDP) 4/ } \\
\hline National & 1.2 & -6.9 & -4.2 & -8.6 & -11.4 & -8.6 & -4.4 & -5.2 & -5.6 & -11.0 & -12.7 \\
\hline General government & 10.9 & 4.7 & 0.4 & -1.7 & 1.7 & -0.3 & -3.7 & -0.3 & 0.3 & 1.6 & 2.4 \\
\hline Financial Enterprises & 1.3 & 0.1 & 1.0 & 1.9 & 0.1 & 3.2 & 3.0 & 1.6 & 0.7 & 1.9 & $\ldots$ \\
\hline Nonfinancial Enterprises 2/3/ & -13.4 & -15.6 & -9.2 & -12.0 & -14.9 & -14.3 & -7.7 & -8.9 & -8.7 & -13.5 & $\ldots$ \\
\hline Households & 2.0 & 3.6 & 3.2 & 2.9 & 1.3 & 2.6 & 3.4 & 2.0 & 1.8 & -1.2 & $\ldots$ \\
\hline Nonprofits Serving Households & 0.3 & 0.3 & 0.3 & 0.4 & 0.4 & 0.3 & 0.6 & 0.5 & 0.3 & 0.1 & $\ldots$ \\
\hline Foreign & -1.2 & 6.9 & 4.2 & 8.6 & 11.4 & 8.6 & 4.4 & 5.2 & 5.6 & 11.0 & 12.7 \\
\hline \multicolumn{12}{|l|}{ Memorandum items: } \\
\hline Household saving rate (share of disposable income) & 2.4 & 1.5 & 1.3 & 1.2 & -0.4 & 0.7 & 1.0 & 1.1 & 1.1 & -2.8 & 0.4 \\
\hline
\end{tabular}

Sources: Statistical Office of Estonia; and staff calculations.

1/ Staff estimates for general government.

2 / Includes discrepancy between net lending and net borrowing of financial accounts.

3 / Includes change in stocks.

4/ Differs from net saving by net capital transfers. 
Table I.3. Estonia: Household Disposable Income, Consumption and Saving, 1993-2003

\begin{tabular}{|c|c|c|c|c|c|c|c|c|c|c|c|}
\hline & 1993 & 1994 & 1995 & 1996 & 1997 & 1998 & 1999 & 2000 & 2001 & 2002 & $20031 /$ \\
\hline \multicolumn{12}{|c|}{ (share of disposable income) } \\
\hline Compensation of employees & 89.0 & 93.6 & 97.6 & 85.3 & 86.2 & 84.0 & 88.5 & 84.8 & 82.9 & 84.8 & 84.0 \\
\hline Non-labor income, net & 16.1 & 14.9 & 17.7 & 19.3 & 18.2 & 17.6 & 16.5 & 16.5 & 16.7 & 16.4 & $\ldots$ \\
\hline Operating surplus and mixed income & 15.1 & 13.0 & 14.8 & 17.7 & 17.0 & 14.8 & 15.4 & 14.6 & 14.1 & 14.0 & $\ldots$ \\
\hline Interest received & 0.4 & 0.4 & 1.2 & 0.6 & 0.9 & 1.0 & 0.8 & 0.8 & 0.8 & 0.6 & $\ldots$ \\
\hline Dividends & 1.2 & 2.1 & 2.2 & 1.7 & 1.7 & 3.1 & 1.5 & 2.8 & 3.8 & 3.6 & $\ldots$ \\
\hline Property income attributed to insurance policy holders & 0.0 & 0.0 & 0.0 & 0.0 & 0.0 & 0.0 & 0.1 & 0.1 & 0.1 & 0.1 & $\cdots$ \\
\hline Rent & 0.0 & 0.0 & 0.0 & 0.0 & 0.0 & 0.0 & 0.0 & 0.0 & 0.0 & 0.0 & $\ldots$ \\
\hline Interest paid & 0.6 & 0.6 & 0.5 & 0.9 & 1.5 & 1.3 & 1.3 & 1.8 & 2.1 & 2.0 & $\ldots$ \\
\hline Other non-labor income, net & 0.0 & 0.0 & 0.0 & 0.0 & 0.0 & 0.0 & 0.0 & 0.0 & 0.0 & 0.2 & $\ldots$ \\
\hline Current transfers received & 32.0 & 29.3 & 24.8 & 30.4 & 32.4 & 35.0 & 33.1 & 34.6 & 35.5 & 36.4 & $\ldots$ \\
\hline Current taxes on income and wealth & 36.6 & 37.0 & 39.1 & 34.0 & 34.3 & 34.3 & 35.7 & 33.4 & 32.1 & 33.5 & $\ldots$ \\
\hline Current transfers paid & 0.5 & 0.8 & 1.1 & 0.9 & 2.4 & 2.3 & 2.4 & 2.5 & 3.0 & 4.1 & $\ldots$ \\
\hline Disposable income & 100.0 & 100.0 & 100.0 & 100.0 & 100.0 & 100.0 & 100.0 & 100.0 & 100.0 & 100.0 & 100.0 \\
\hline Final consumption expenditure & 97.6 & 98.5 & 98.7 & 98.8 & 100.4 & 99.3 & 99.0 & 98.9 & 98.9 & 102.8 & 99.6 \\
\hline Net saving & 2.4 & 1.5 & 1.3 & 1.2 & -0.4 & 0.7 & 1.0 & 1.1 & 1.1 & -2.8 & 0.4 \\
\hline \multicolumn{12}{|c|}{ (share of GDP) } \\
\hline Compensation of employees & 49.1 & 54.0 & 53.8 & 49.9 & 48.9 & 47.9 & 50.2 & 47.2 & 46.0 & 46.0 & 46.4 \\
\hline Non-labor income, net & 8.9 & 8.6 & 9.8 & 11.3 & 10.3 & 10.0 & 9.4 & 9.2 & 9.3 & 8.9 & $\ldots$ \\
\hline Operating surplus and mixed income & 8.4 & 7.5 & 8.1 & 10.4 & 9.7 & 8.4 & 8.7 & 8.1 & 7.8 & 7.6 & $\ldots$ \\
\hline Interest received & 0.2 & 0.3 & 0.7 & 0.4 & 0.5 & 0.6 & 0.5 & 0.4 & 0.5 & 0.3 & $\ldots$ \\
\hline Dividends & 0.6 & 1.2 & 1.2 & 1.0 & 1.0 & 1.8 & 0.8 & 1.6 & 2.1 & 2.0 & $\ldots$ \\
\hline Property income attributed to insurance policy holders & 0.0 & 0.0 & 0.0 & 0.0 & 0.0 & 0.0 & 0.0 & 0.0 & 0.0 & 0.0 & $\ldots$ \\
\hline Rent & 0.0 & 0.0 & 0.0 & 0.0 & 0.0 & 0.0 & 0.0 & 0.0 & 0.0 & 0.0 & $\ldots$ \\
\hline Interest paid & 0.4 & 0.3 & 0.3 & 0.5 & 0.8 & 0.8 & 0.7 & 1.0 & 1.2 & 1.1 & $\cdots$ \\
\hline Other non-labor income, net & 0.0 & 0.0 & 0.0 & 0.0 & 0.0 & 0.0 & 0.0 & 0.0 & 0.0 & 0.1 & $\ldots$ \\
\hline Current transfers received & 17.7 & 16.9 & 13.7 & 17.8 & 18.4 & 20.0 & 18.8 & 19.3 & 19.7 & 19.7 & $\cdots$ \\
\hline Current taxes on income and wealth & 20.2 & 21.4 & 21.5 & 19.9 & 19.5 & 19.6 & 20.2 & 18.6 & 17.8 & 18.2 & $\ldots$ \\
\hline Current transfers paid & 0.3 & 0.5 & 0.6 & 0.5 & 1.4 & 1.3 & 1.4 & 1.4 & 1.7 & 2.2 & $\ldots$ \\
\hline Disposable income & 55.2 & 57.7 & 55.1 & 58.5 & 56.7 & 57.0 & 56.7 & 55.6 & 55.6 & 54.2 & 55.2 \\
\hline Final consumption expenditure & 53.9 & 56.8 & 54.3 & 57.8 & 56.9 & 56.6 & 56.1 & 55.0 & 55.0 & 55.7 & 55.0 \\
\hline Net saving & 1.3 & 0.9 & 0.7 & 0.7 & -0.2 & 0.4 & 0.5 & 0.6 & 0.6 & -1.5 & 0.2 \\
\hline
\end{tabular}

Sources: Statistical Office of Estonia; and staff calculations and estimates.

1/ Staff estimate for disposable income. 
Table I.4. Estonia: Business Indicators, 1996-2003

(In percent, unless otherwise noted)

\begin{tabular}{|c|c|c|c|c|c|c|c|}
\hline & 1996 & 1997 & 1998 & 1999 & 2000 & 2001 & 2002 \\
\hline \multicolumn{8}{|l|}{ Debt-equity ratio } \\
\hline Overall economy & 60.0 & 68.0 & 69.0 & 62.0 & 61.0 & 64.0 & 64.0 \\
\hline Manufacturing & 65.0 & 65.0 & 70.0 & 77.0 & 73.0 & 68.0 & 63.0 \\
\hline \multicolumn{8}{|l|}{ Return on equity } \\
\hline Overall economy & 3.4 & 8.6 & 3.8 & -0.3 & 15.0 & 12.4 & 18.8 \\
\hline Manufacturing & -1.5 & 10.1 & 1.7 & -3.5 & 17.4 & 19.5 & 20.3 \\
\hline \multicolumn{8}{|l|}{ Return on assets } \\
\hline Overall economy & 1.5 & 3.7 & 1.6 & -0.2 & 7.0 & 5.8 & 8.9 \\
\hline Manufacturing & -0.7 & 4.4 & 0.8 & -1.4 & 7.4 & 8.6 & 9.4 \\
\hline \multicolumn{8}{|c|}{ Total profit to net sales } \\
\hline Overall economy & 2.3 & 3.4 & 2.7 & 2.2 & 4.3 & 3.7 & 4.7 \\
\hline Manufacturing & 2.3 & 4.6 & 3.0 & 3.2 & 5.4 & 5.7 & 5.9 \\
\hline
\end{tabular}

Source: Statistical Office of Estonia. 
Table I.5. Estonia: Financial Survey, 1996-2003

\begin{tabular}{|c|c|c|c|c|c|c|c|c|}
\hline & 1996 & 1997 & 1998 & 1999 & 2000 & 2001 & 2002 & 2003 \\
\hline \multicolumn{9}{|c|}{ (Percent of GDP) } \\
\hline Net Foreign Assets & 12.0 & 7.4 & 6.5 & 9.8 & 9.8 & 11.8 & 6.6 & -0.9 \\
\hline Domestic Credit & 20.8 & 30.4 & 30.9 & 42.0 & 48.0 & 55.1 & 63.9 & 73.9 \\
\hline General government & -1.6 & -2.5 & -1.2 & 0.0 & -1.0 & -0.4 & -0.3 & -0.1 \\
\hline Private sector & 21.6 & 26.0 & 24.7 & 32.0 & 34.1 & 37.0 & 41.6 & 49.8 \\
\hline Enterprises & 18.3 & 19.8 & 19.2 & 24.7 & 25.2 & 25.8 & 27.2 & 30.5 \\
\hline Households & 3.2 & 6.1 & 5.4 & 7.2 & 8.9 & 11.2 & 14.4 & 19.3 \\
\hline Other financial institutions & 3.8 & 7.7 & 8.1 & 0.1 & 12.5 & 15.0 & 13.5 & 9.2 \\
\hline Other sectors & -2.9 & -0.7 & -0.7 & 10.0 & 2.3 & 3.5 & 9.2 & 15.0 \\
\hline Other items (net) & -6.3 & -7.9 & -10.2 & -19.5 & -22.0 & -27.7 & -31.7 & -33.1 \\
\hline Broad Money & 26.5 & 30.0 & 27.2 & 32.3 & 35.8 & 39.1 & 38.8 & 40.0 \\
\hline Money & 20.2 & 20.5 & 16.7 & 21.2 & 22.5 & 23.9 & 23.3 & 24.5 \\
\hline Qusai-Money & 6.4 & 9.5 & 10.5 & 11.1 & 13.3 & 15.2 & 15.5 & 15.5 \\
\hline \multicolumn{9}{|c|}{ (Percent change) } \\
\hline Net Foreign Assets & $\ldots$ & -24.4 & 0.6 & $\ldots$ & 13.4 & 35.0 & -36.9 & -113.8 \\
\hline Domestic Credit & $\ldots$ & 78.3 & 16.5 & $\ldots$ & 29.9 & 29.1 & 30.0 & 24.6 \\
\hline General government & $\ldots$ & 87.8 & -45.8 & $\ldots$ & $\ldots$ & -56.0 & -2.5 & -58.3 \\
\hline Private sector & $\ldots$ & 47.0 & 8.9 & $\ldots$ & 21.3 & 21.9 & 26.1 & 29.0 \\
\hline Enterprises & $\ldots$ & 32.1 & 11.1 & $\ldots$ & 15.6 & 15.1 & 18.4 & 20.8 \\
\hline Households & $\ldots$ & 132.0 & 1.7 & $\ldots$ & 40.6 & 41.0 & 43.9 & 44.6 \\
\hline Other financial institutions & $\ldots$ & 144.5 & 21.1 & $\ldots$ & $\ldots$ & 34.6 & 0.6 & -26.5 \\
\hline Other sectors & $\ldots$ & -71.3 & 9.6 & $\ldots$ & -73.5 & 70.4 & 192.6 & 76.5 \\
\hline Other items (net) & $\ldots$ & 53.3 & 47.9 & $\ldots$ & 28.7 & 41.6 & 28.0 & 12.4 \\
\hline Broad Money & $\ldots$ & 37.8 & 4.2 & $\ldots$ & 25.7 & 23.0 & 11.2 & 10.9 \\
\hline Money & $\ldots$ & 24.0 & -6.3 & $\ldots$ & 20.4 & 19.5 & 9.3 & 13.0 \\
\hline Qusai-Money & $\ldots$ & 81.5 & 26.9 & $\ldots$ & 35.8 & 29.0 & 14.2 & 7.7 \\
\hline
\end{tabular}

Sources: Bank of Estonia; and staff calculations.

1/ Data for 1996-98 cover the banking system, and for 1999-2003 include the leasing sector as well. 
Table I.6. Estonia: Banking Sector Indicators, 1996-2003

\begin{tabular}{lrrrrrrrr}
\hline & 1996 & 1997 & 1998 & 1999 & 2000 & 2001 & 2002 & 2003 \\
\hline Average capital adequacy ratio & $12.1 \%$ & $13.5 \%$ & $17.0 \%$ & $16.1 \%$ & $13.2 \%$ & $14.4 \%$ & $15.3 \%$ & $14.5 \%$ \\
Non-performing loans (in percent of total loans) & $1.3 \%$ & $1.2 \%$ & $1.4 \%$ & $1.7 \%$ & $1.0 \%$ & $1.3 \%$ & $0.8 \%$ & $0.4 \%$ \\
Leverage ratio & 8.4 & 7.1 & 4.8 & 5.2 & 6.6 & 6.6 & 7.3 & 8.1 \\
Net interest margin & 7.0 & 5.6 & 4.3 & 4.2 & 4.3 & 3.9 & 3.6 & 2.9 \\
Return on assets & $2.9 \%$ & $3.3 \%$ & $-1.9 \%$ & $1.5 \%$ & $1.2 \%$ & $2.7 \%$ & $1.6 \%$ & $1.7 \%$ \\
Return on equity & & & & & & & & \\
\end{tabular}

Sources: Bank of Estonia; Financial Supervisory Authority. 


\section{Labor and Product Market Flexibility and Productivity Catch-up IN THE RUN-UP TO THE AdOPTION OF THE EURO ${ }^{1}$}

\section{A. Introduction}

1. Estonia joined the ERM II mechanism in June 2004, and is expected to adopt the euro following a two year transition period. By unilaterally maintaining its currency board during the ERM II participation, and with the euro adoption to follow in the near future, Estonia has committed itself to a permanent fixed exchange rate regime. In these circumstances economic theory teaches that it is particularly important for economies with rigid exchange rate regimes to have enough flexibility in the product and labor market in order to minimize the costs of adjustment to adverse shocks. The intuition is straightforward. If the most important price in a small open economy - the exchange rate - can not move, then it is critical that other prices (both input and output) be flexible if the economy is going to grow and be able to adapt to unexpected circumstances. This market flexibility is even more important in the case of Estonia where high current account deficits have persisted for some time and increased its vulnerability to external shocks.

2. This note makes use of the IMF's new Global Econometric Model (GEM) to investigate and quantify the role of market flexibility in Estonia. It does this by comparing the results of simulations made under different assumptions about labor market and goods market flexibility as well as different assumptions about productivity growth in both the tradables and nontradables sectors.

3. GEM is a large multi-country macroeconomic model derived completely from microeconomic theoretic foundations. ${ }^{2}$ Having a theoretically derived model with both tradables and nontradables goods is a useful tool for examining issues of international interdependence. In particular, it provides insights about real exchange rate and current account adjustments based upon fundamental structural parameters. Because the model can incorporate different degrees of monopolistic competition in labor and goods markets, ${ }^{3}$ it is

${ }^{1}$ Prepared by Emil Stavrev.

${ }^{2}$ GEM is a new open economy dynamic stochastic general equilibrium (DSGE) model at the forefront of macroeconomic model design. See the Appendix for a more detailed explanation of the version of GEM used in this paper. For a complete description of GEM's derivation, the specification of its structural equations, and more details on its dynamic adjustment properties see Laxton and Pesenti (2003) and Hunt and Rebucci (2003).

${ }^{3}$ Wages can contain a markup over the marginal rates of substitution between consumption and leisure and prices can contain a markup over the marginal costs of production. The magnitudes of these markups represent the degree of real rigidity in the corresponding markets. Therefore, the model is well suited for examining the macroeconomic implications of flexibility of labor and product markets on propagation of shocks. 
also well suited to study the effects of labor market and product market rigidities on the propagation of various shocks to the economy. And it should be noted that GEM has rational expectations (i.e., today's expectations of key variables today are, in fact, realized tomorrow in simulation) and thus GEM is less susceptible to the Lucas Critique than more conventional models.

4. In this paper, a three-country version of GEM is used. The world economy consists of three blocks that have been calibrated to represent Estonia, the Euro area (EU) and the rest of the world (ROW). The main focus of the calibration has been on the long-run equilibrium characterization of the three economies, particularly their trading relationships and their relative degrees of labor and goods market competition. Therefore, the analysis centers on the medium- and long-term trends and not short-term adjustment dynamics. ${ }^{4}$

\section{The main findings of the paper are:}

- $\quad$ Flexible labor and product markets facilitate productivity catch-up.

- Increased labor and product market flexibility lowers the adjustment costs of adverse external interest rate shocks; the output loss in Estonia from an interest rate increase in the EU is smaller when labor and product markets are flexible.

- $\quad$ Productivity growth in Estonia results in an initial period of higher current account deficits, real appreciation, and higher inflation because of the Balassa-Samuelson effect if gains in tradables productivity are much higher than the gains in nontradables productivity.

6. The remainder of the paper is structured as follows. Section B discusses the determinants of labor and product market flexibility and quantifies the relative efficiencies of labor and goods markets in Estonia and the euro area. For the EU, estimates from the literature are used, while for Estonia, due to the lack of direct empirical estimates of markups in labor and product markets, they are calibrated using studies in the literature comparing the Estonian labor and product markets with those of the EU. Section C presents the GEM simulation results under alternative assumptions of labor and goods market flexibility. It also examines how the Estonian economy reacts to foreign interest rate shocks under different assumptions about market rigidity and presents the results of simulating productivity catchup in Estonian with a special view on the effect of the Maastricht criteria. Section D concludes.

\footnotetext{
${ }^{4}$ Many of the model parameters that more directly affect the short-run dynamic adjustment properties are assumed for simplicity to be identical in all three blocks.
} 


\section{B. Determinants and Estimates of Labor and Goods Markets Flexibility}

\section{Labor Markets}

7. Labor market flexibility is modeled here by the degree of real wage rigidity. The degree of real wage rigidity is governed by the magnitude of the markup of the real wage in excess of the

marginalrate of substitution between consumption and leisure, or, in what amounts to the same thing, the marginal cost of labor, and depends, in large measure, on the institutions in place and structural policies in the labor market. ${ }^{5}$ In a perfectly flexible labor market the markup is equal to one, while in a rigid labor market the markup is higher than

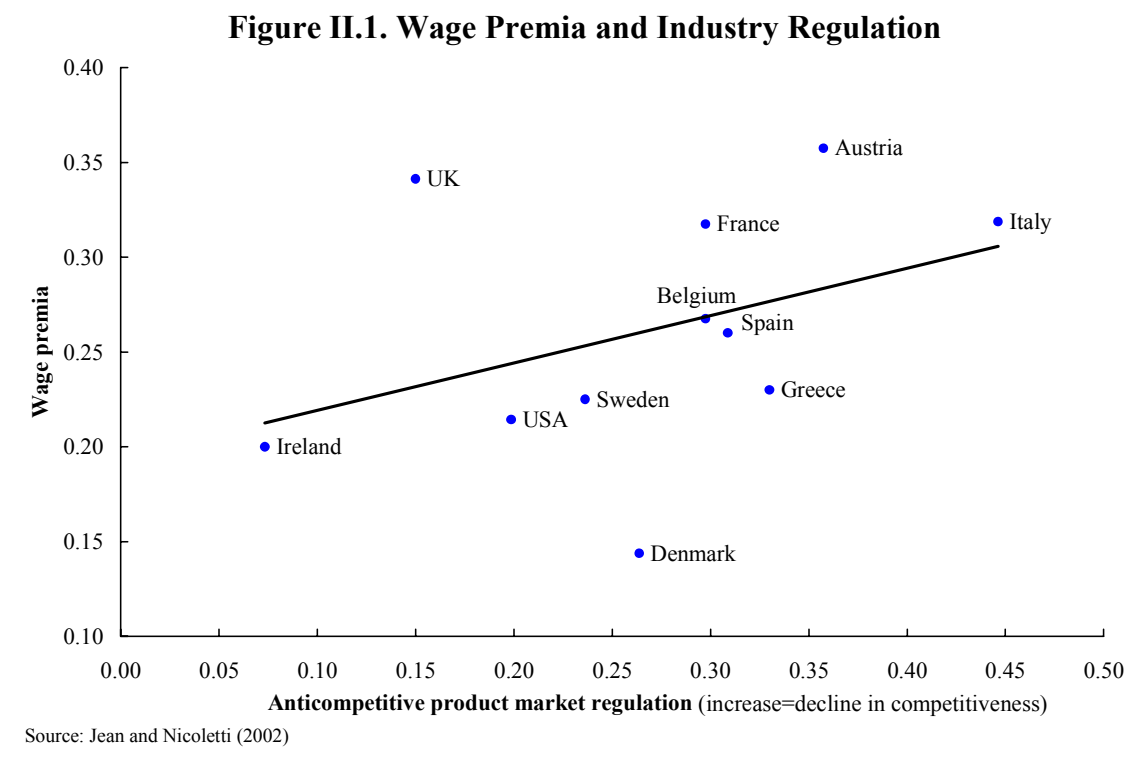
one. This markup parameter is changed in the simulations to generate the macro economic effects of alternative labor market flexibility assumptions.

8. Empirical estimates in the literature are used to calibrate labor market markups for the three blocks (Estonia, EU, and ROW) in this note. The wage markup in the EU is calibrated to be 25 percent. This calibration is based on a study by Jean and Nicoletti (2002). In a panel using industrial data from the OECD countries, they estimated wage markups in several OECD countries and show that wage markups increase with the increase of overall structural rigidities (labor and product market regulations) in the economy. The calibration of the wage markup in Estonia is somewhat more complicated because there are no direct estimates in the literature. However, as shown in Eamets (2003), Hinnosaar and Rõõm (2003), Eamets and Kallaste (2003), Backé et al. (2004), and in OECD report (2003), the Estonian labor market is generally thought to be somewhat more flexible than EU labor markets. Using this information, and the findings in Jean and Nicoletti, the wage markup in Estonia is calibrated to be 15 percent (i.e., the coefficient in the wage markup equation is

\footnotetext{
${ }^{5}$ Factors that influence real wage rigidities are minimum wage legislation, the generosity of unemployment insurance and welfare benefits, legislation that affects unionization and wage bargaining process, professional licensing and qualification requirements, and immigration policy.
} 
equal to 1.15). Regarding the ROW, somewhat arbitrary the wage markup is assumed to be 25 percent, the same as in the EU.

\section{Goods Markets}

\section{Goods market competitiveness is measured by the markup of prices over the marginal costs of production.}

These markups, in general, Table II.1. Average Markup Ratios by Market Structure Type depend on factors such as import licensing, quotas, product standards, public and private monopolies, administrative burdens on new firm establishment, and access to capital. As a result of imperfections in goods markets, prices are higher than they otherwise would be, output is lower and unemployment is higher. Although we consider labor and goods market markups

\begin{tabular}{lcc}
\hline & Fragmented industries & Segmented industries \\
\hline USA & 1.11 & 1.22 \\
Japan & 1.21 & 1.23 \\
Germany & 1.21 & 1.29 \\
France & 1.16 & 1.25 \\
Italy & 1.18 & 1.19 \\
UK & 1.10 & 1.19 \\
Canada & 1.17 & 1.25 \\
Australia & 1.18 & 1.26 \\
Belgium & 1.16 & 1.15 \\
Denmark & 1.15 & 1.24 \\
Finland & 1.16 & 1.23 \\
Netherlands & 1.16 & 1.24 \\
Norway & 1.15 & 1.24 \\
Sweden & 1.12 & 1.20 \\
All countries & 1.16 & 1.23 \\
\hline
\end{tabular}
separately they are not necessarily independent. Markups in goods markets indicate the presence of economic rents and may induce rent seeking behavior on the part of workers, leading to markups in labor markets. As in the case of labor market, in a perfectly competitive goods market the markup is equal to one (i.e., price is equal to marginal cost), while in a monopolistic market the markup is greater than one.

\section{The goods market markup in the euro area is calibrated based on empirical} estimates in the literature (see Table II.1). ${ }^{6}$ Two observations are worth noting: first, as expected, the estimated markups in are higher for industries with less competition (segmented industries) compared to industries with more competition (fragmented industries); and, second, smaller EU countries have lower markups than bigger EU countries. Using the estimates from Martins et al. (1996), the product market markups in the EU are calibrated at 16 percent. Regarding product markups in Estonia, because there are no estimates in the literature, two scenarios were considered. In the first scenario, called flexible product markets, the Estonian product markets are assumed to be more competitive than the rest of the EU and the markup is set at 12 percent - the lowest in the study. In the second scenario, called rigid product markets, product market competition in Estonia is assumed to be the same as in the EU and the markup is set at 16 percent.

\footnotetext{
${ }^{6}$ The methodology is completely analogous to that used in calibrating the labor market parameter, described above.
} 


\section{The Simulation Results}

11. In this section we examine how the Estonian economy might evolve in the medium- to long-term under different assumptions about labor and product market flexibility. To this end, we performed several simulations. First, we compared the effect of rigid versus flexible labor markets. To do this we establish a baseline to use as a reference point in which the Estonian labor markup is set at 15 percent. We then increase this to 25 percent, the EU level, and look to see the effect of the increased rigidity on such things as GDP, consumption, investment, trade and prices. The results are shown in Figure II.2. In brief, increased labor market rigidity is inimical to the economy: real GDP is less by about $1 \frac{1}{2}$ percent by the end of the simulation; consumption, investment, and trade are all lower as well; and prices are higher. The reason for this result is that a more rigid labor market amplifies economic inefficiencies and nominal rigidities. Firms gain market power, prices increase, and competitiveness declines, leading to higher current account deficit and lower economic activity variables. Simulations of increased labor market flexibility — not shown here-show symmetrical results: output increases and the inflation falls.

\section{The second set of simulations focused on the effects of increased rigidity in} output markets. This was modeled by increasing the output price markups in both the tradables and nontradables goods sectors to show a loss of output market competitiveness. The baseline scenario assumes that the Estonian economy is, relative to the rest of the world, competitive with an output markup of 12 percent (versus 16 percent in the EU). In the counterfactual simulation, the Estonian markup is raised to the EU level. The results are shown in Figure II.3. Again, increasing market rigidities - this time in the output markethas detrimental effects on real GDP, consumption, investment, trade, and prices. The intuition is clear: as competition fades away and firms gain market power they increase prices, which leads to a decline of output and consumption. 
Figure II.2. Estonia: The Impact of Rigid Labor Market

(Percent or percentage point deviation from baseline)
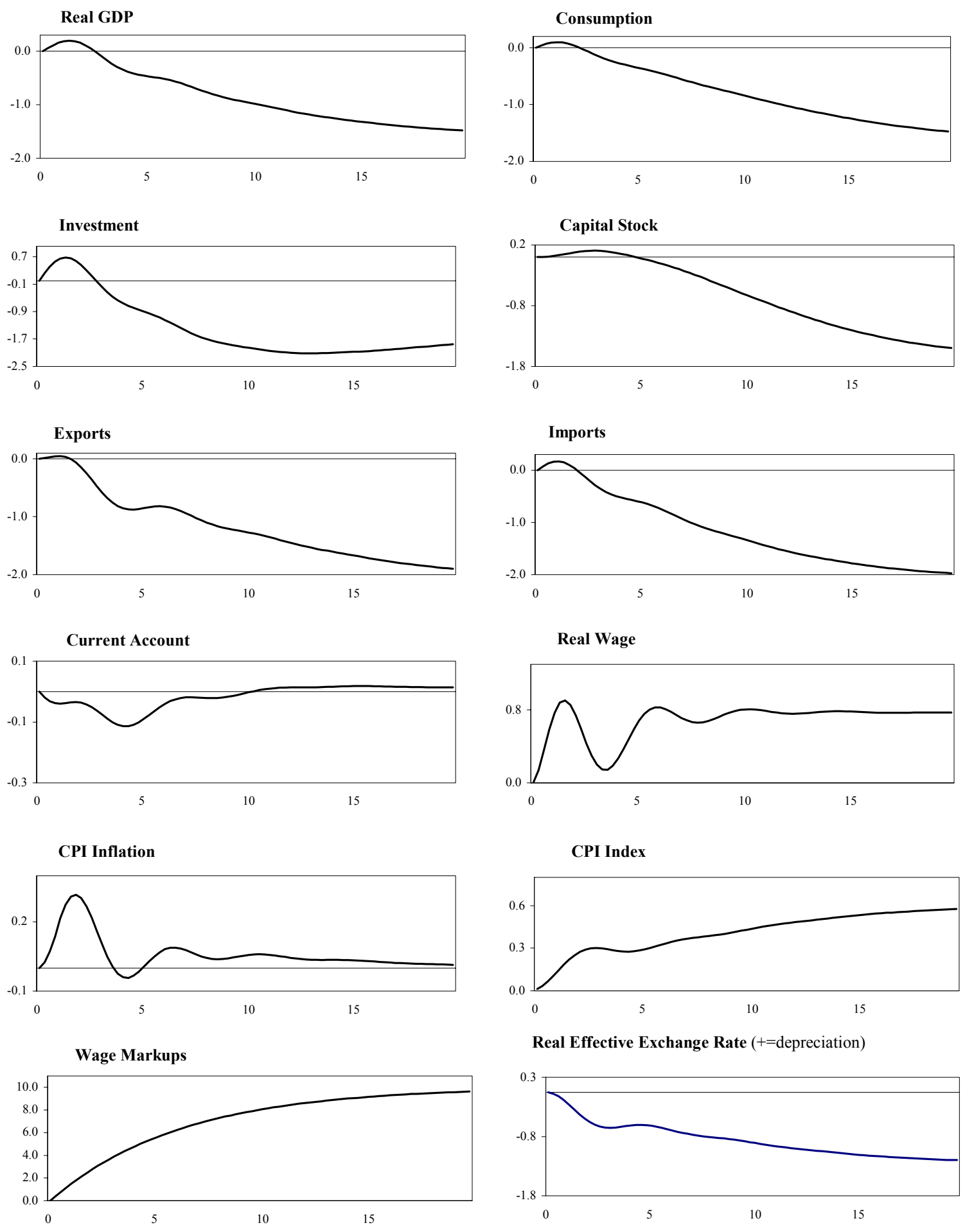

Real Effective Exchange Rate (+=depreciation)

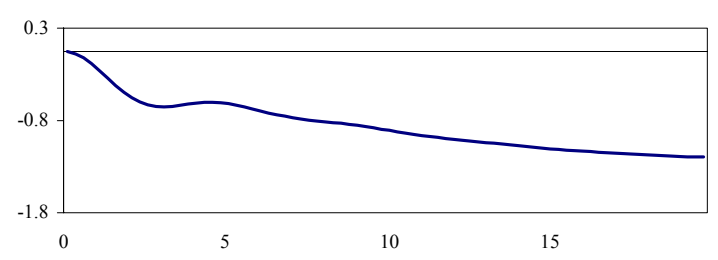

Number of quarters on horizontal axis. 
Figure II.3. Estonia: Increase of Markups in Tradables and Nontradables Goods Prices (Percent or percentage point deviation from baseline)
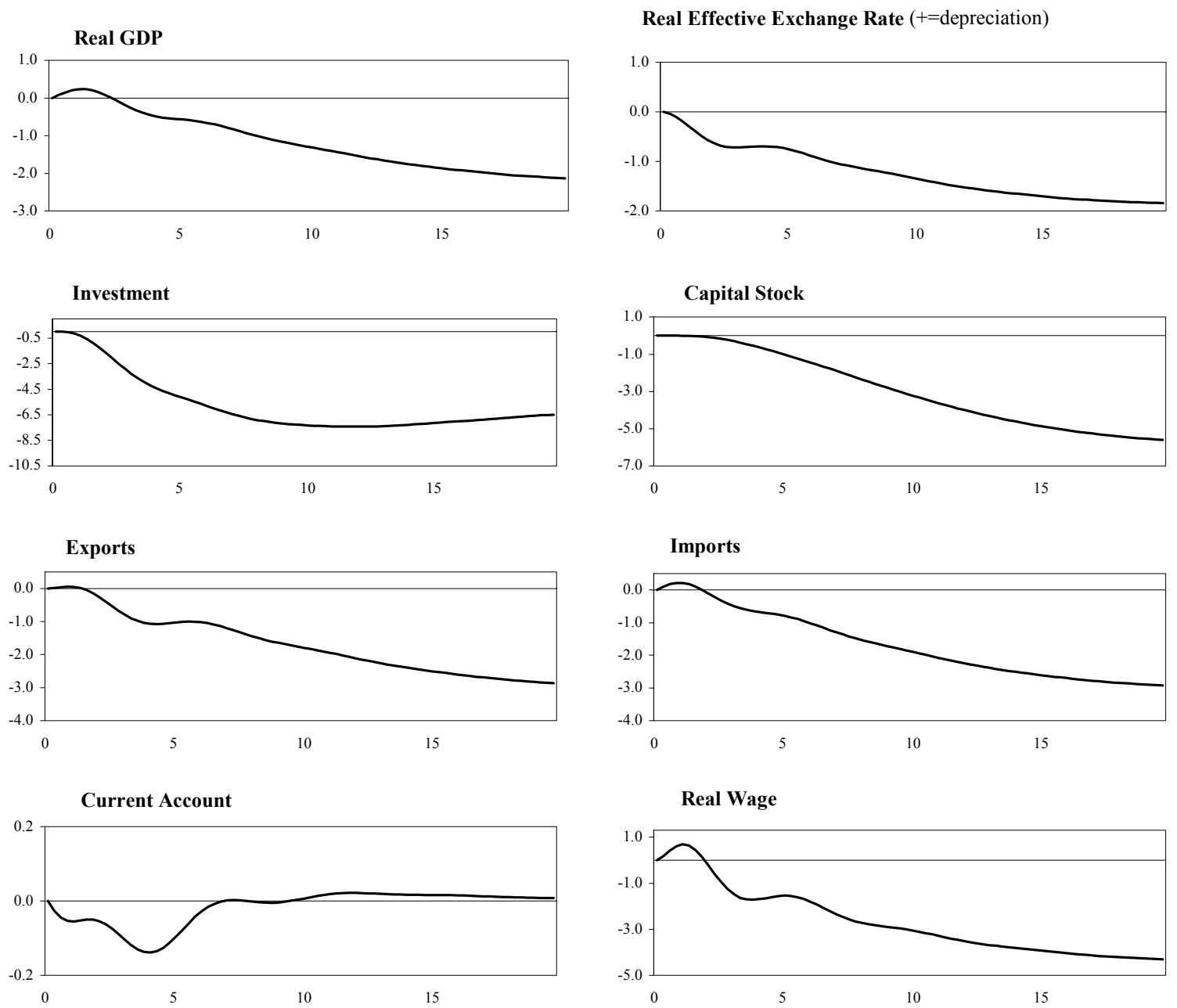

CPI Inflation

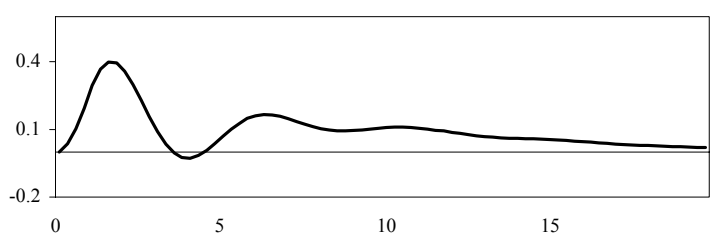

CPI Index

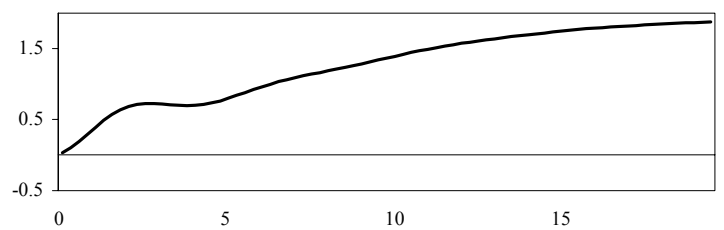

Markup in Nontradable Goods Prices
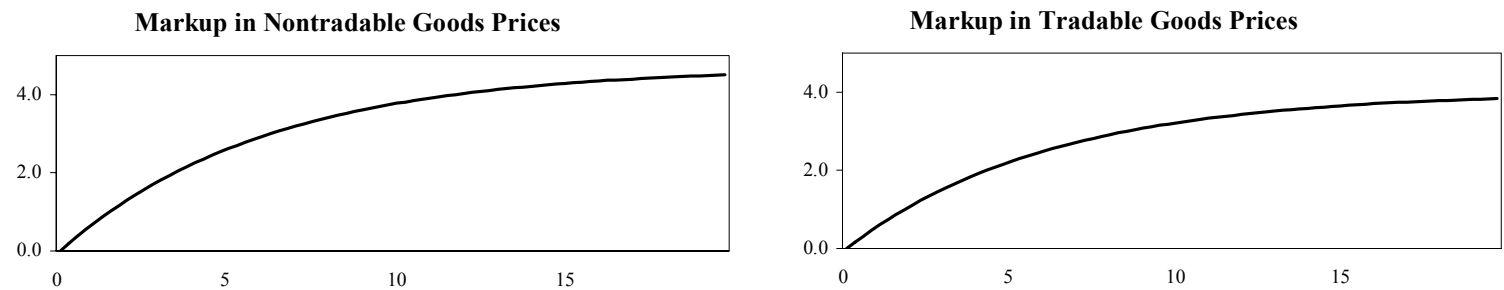

Number of quarters on horizontal axis 
13. Structural rigidities in labor and product markets exacerbate the impact of adverse external shocks on economic activity. The above simulations demonstrate how important flexible input and output markets are. This can be further seen by investigating how the Estonian economy might be expected to react to an external interest rate shock under different assumptions of market rigidity. Market flexibility is especially important for fixed exchange rate regimes because labor and product market flexibility play an enhanced role in helping the economy adjust to external shocks and thereby minimize the costs of the adjustment. This can be clearly seen in the following set of simulations. First the model was set up with relatively flexible labor and output markets. The wage and output markups were set to the relatively flexible levels discussed above (15 and 12 percent, respectively). Then the model was shocked with a 100 basis point increase in the euro interest rate while the exchange rate was held constant. There was, not unexpectedly, some output loss, but it was less than when the experiment was replicated with more rigid labor and output markets. In this simulation both the EU and Estonian wage and good markups were held to 25 and 16 percent respectively.

14. The model simulations show that Estonia would perform much worse under the "rigid markets" scenario in response to an adverse interest rate shock. As the results in Table II.2 show, short-term output loss is significant. As a result of a one-year, 100 basis point increase in nominal interest rates in the EU, the 3 -year cumulative loss in real GDP is 2 percentage points under the "rigid markets" scenario compared to the "flexible markets" scenario; investment performance is even worse (the 3-year cumulative loss in investment is 5 percentage points) suggesting much higher loses over the long-term. In addition, due to lower competition in product markets and higher markups in the labor market, inflation is higher in the "rigid markets" case. This leads to a deterioration of the competitiveness of the economy and, as a consequence weaker export performance.

Table II.2. Estonia: Labor and Product Market Flexibility and Propagation of Shocks 1/

(Percent or percentage point)

\begin{tabular}{|c|c|c|c|}
\hline Real GDP & -2.0 & Consumption & -1.0 \\
\hline Investment & -5.0 & Capital Stock & -1.0 \\
\hline Exports & -3.0 & Imports & -2.2 \\
\hline Current Account & -0.3 & & \\
\hline CPI Index & 0.5 & $\begin{array}{l}\text { Real Effective Exchange Rate } \\
\qquad(+=\text { depreciation })\end{array}$ & -0.5 \\
\hline
\end{tabular}

1/ Cumulative 4-year response to a 1 percentage point temporary (1-year) interest rate increase in the EU; Difference between rigid labor and product markets and flexible markets in Estonia. 
15. The final set of simulations attempt to quantify the Balassa-Samuelson effect during ERM II participation on inflation and therefore in meeting the Maastricht inflation criterion in the short term. In the long-term, in the context of a common currency area, it is interesting to learn the impact of productivity increases on the main macroeconomic variables. To get some insights about the above issues, we performed the following two simulations. First, in line with the high FDI inflows in Estonia, we assume a 100 percent permanent increase in tradables productivity during the simulation. Second, because a substantial part of nontradables in Estonia is high tech services, such as banking services, we assume that nontradable productivity also increase, but by a lesser amount. In this case by 25 percent over the simulation. These two shocks have the following impact on economic activity:

- While as a result of a larger increase in tradables productivity (the Balassa-Samuelson effect), inflation increases, but gains in nontradables productivity could partially offset this. This result suggests that if the Balassa-Samuelson effect in Estonia is strong, inflation could increase substantially and violate the Maastricht inflation criterion in the short-run.

- $\quad$ Labor and product market flexibilities ensure a relatively fast catch-up of Estonian productivity to the EU levels. As shown on Figure II.4, it takes around 20 to 25 years for productivity in tradables to double and productivity in nontradables to increase by 25 percent.

- $\quad$ The catch-up in productivity is accompanied with substantial gains in the real variables. At the new steady state, as a result of the cumulative effect of tradables and nontradables productivity increases, real GDP and consumption are higher by around a one-third, compared to the baseline scenario.

- $\quad$ Following a sizable increase in tradables productivity, competitiveness improves and leads to an initial deterioration of the current account deficit as the income effect dominates the price effect. On the contrary, an increase in nontradables productivity results in lower current account deficit. 
Figure II.4. Permanent Productivity Increase in Estonia (Percent or percentage point deviation from baseline)
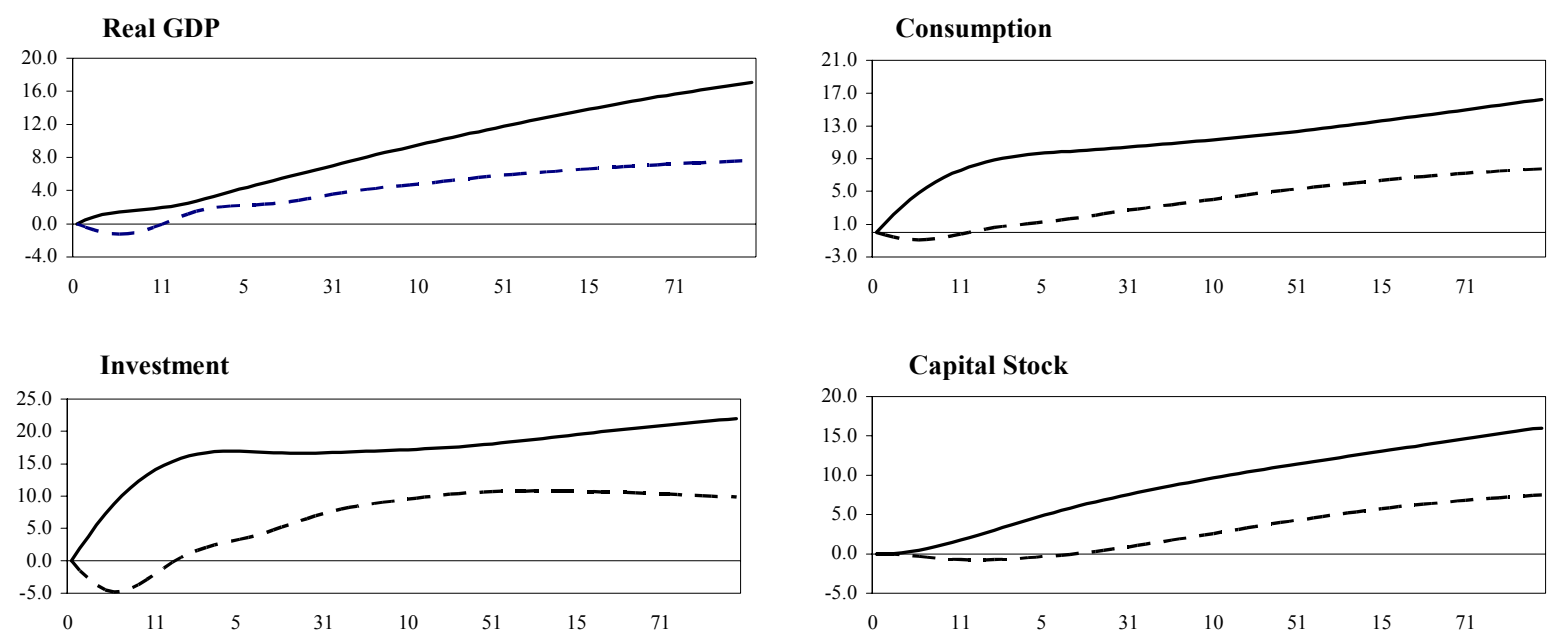

Exports
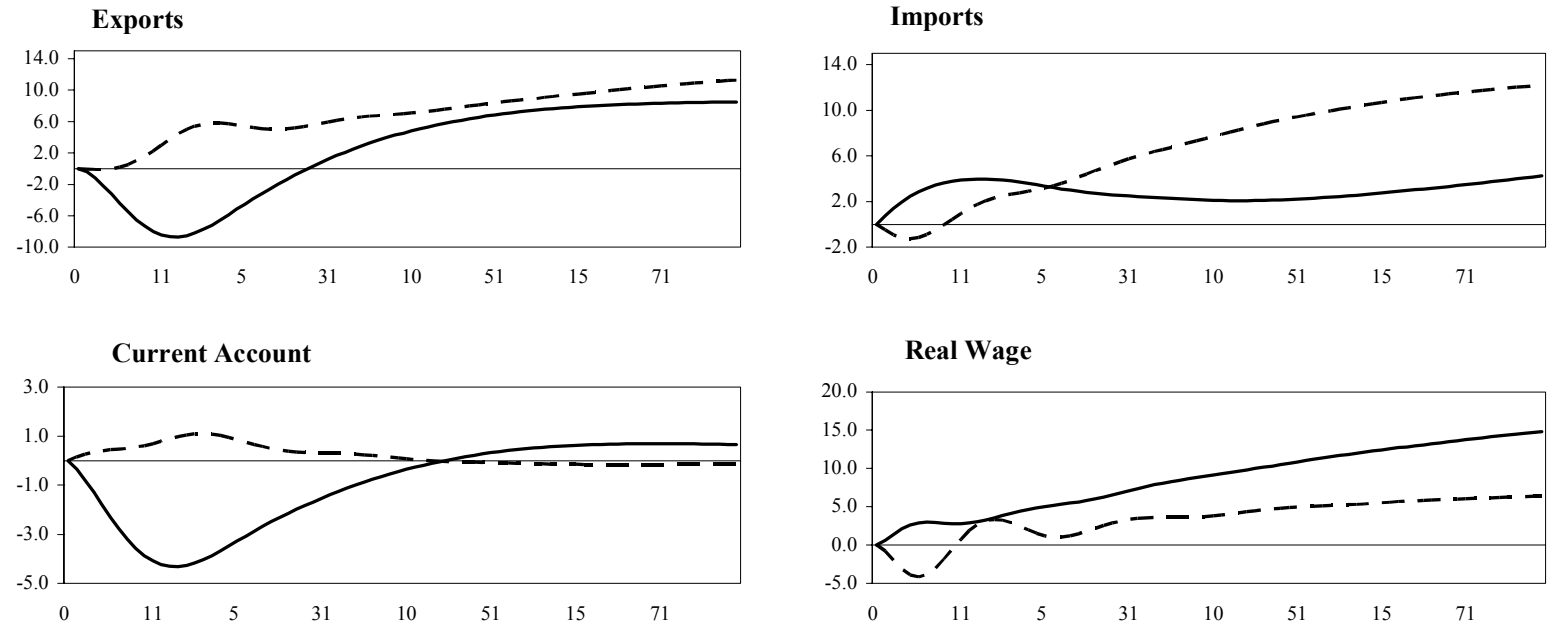

\section{CPI Inflation}

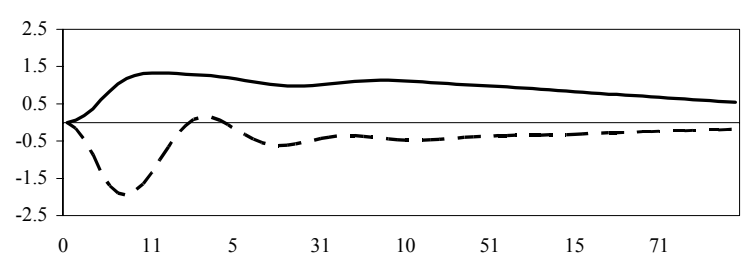

Real Effective Exchange Rate (+=depreciation)

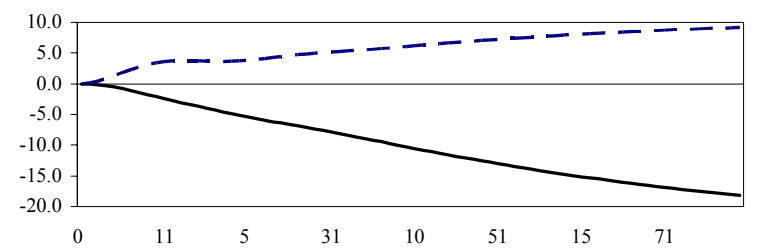

Tradables productivity doubles $=$ solid lines, Nontradables productivity increases by $1 / 4=$ dashed lines, Number of quarters on horizontal axis 


\section{Conclusions}

16. This paper has presented estimates of the impact of market flexibility and productivity increases in Estonia using GEM. Although the results should be interpreted carefully because the calibration of the model focused only on the long-run properties for the main macroeconomic variables, several important results come out. First, labor and product market flexibilities provide a significant degree of protection against adverse external shocks when the exchange rate is fixed. Second, the increase in tradables productivity during the catch-up to EU levels is associated with higher current account deficits as the economy increases its productive capacity.

17. In the context of Estonia's ERM II participation (and consequently euro adoption), productivity catch-up could result in a positive inflation differential with the euro area. As the productivity in tradables reaches the EU levels, CPI inflation in Estonia is seen to be higher than EU inflation. However, as the simulation results suggest, if increases in tradables productivity goes together with increases in nontradables productivity, real income in Estonia could reach the EU levels without substantial inflation differential with the EU area. 


\section{References}

Backé, P., and C. Thimann, (2004) "The Acceding Countries' Strategies towards ERM II and the Adoption of the Euro: an Analytical Review," ECB Occasional Paper, No. 10

Eamets, R., 2003, "How Labor Markets in the Baltic States Adjust to Macroeconomic Shocks", presented a seminar on Labor Market Research in Estonia organized by the Bank of Estonia (http://www.eestipank.info/search/en?query=Seminar+in+2003).

Eamets, R., and E. Kallaste, 2003, “The Role of Trade Unions in Labor Market Flexibility: the Case of Estonia", presented a seminar on Labor Market Research in Estonia organized by the Bank of Estonia (http://www.eestipank.info/search/en?query=Seminar+in+2003).

Hinnosaar, M., and T. Rõõm 2003, "Labor Market Impact of the Minimum Wage in Estonia: an Empirical Analysis", presented a seminar on Labor Market Research in Estonia organized by the Bank of Estonia (http://www.eestipank.info/search/en?query=Seminar+in+2003).

Honohan P., and P. Lane, 2003, "Divergent Inflation Rates in EMU,” Forthcoming in Economic Policy 37.

Hunt B., and A. Rebucci 2003, "The US Dollar and the Trade Deficit: What Accounts for the Late 1990s?”, IMF Working Paper, 03/194.

Jean, S., and G. Nicoletti, 2002, "Product Market Regulation and Wage Premia in Europe and North America: An Empirical Investigation," OECD Economics Department Working Paper No. 318.

Laxton D., and P. Pesenti (2003), "Monetary Policy Rules for Small, Open, Emerging Economies," Journal of Monetary Economics, 50, pp 1109-1146.

Nicoletti, G., and S. Scarpetta, 2003, "Regulation, Productivity, and Growth: OECD Evidence," World Bank Policy Research Working Paper 2944, (January).

OECD Report, 2003, "Labor Market and Social Policies in the Baltic Countries"

Olivera Martins J., S. Scarpetta and D. Pilat, 1996, "Mark-up Pricing, Market Structure and the Business Cycle,” OECD Economic Studies No. 27.

Schorfheide, F., 2002, “Loss Function-Based Evaluation of DSGE Models," Journal of Applied Econometrics, Vol. 15, No. 6, pp 645-670, (November/December).

Smets, F., and R. Wouters, 2002, “An Estimated Stochastic Dynamic General Equilibrium Model of the Euro Area," ECB Working Paper no. 171 (August). 


\title{
NON-TECHNICAL SUMMARY OF GEM
}

\begin{abstract}
A. Overview
1. GEM is a large multi-country macroeconomic model derived completely from microeconomic optimizing foundations. The version of GEM used here, characterizes the behavior of three blocks: Estonia, the euro area and the ROW, based on Estonia's trading partners. In each blocks there are households, firms, and a government. Households maximize utility derived from the consumption of goods and leisure. Firms combine capital and labor to maximize the net income from the production of non-tradable and tradable intermediate goods. Firms also produce the final non-tradable good. Governments consume goods financed through non-distortionary taxes and adjust short-term nominal interest rates to provide nominal anchors. ${ }^{1}$
\end{abstract}

\section{B. Households}

2. Households are the monopolistic suppliers of differentiated labor inputs to all domestic firms, and live infinitely and consume the non-tradable final good. There is habit persistence in household consumption behavior, which contributes to real rigidities in economic adjustment. Monopoly power in labor supply implies that the wages households receive contain a markup over the marginal rate of substitution between consumption and leisure. Because wage contracts are subject to adjustment costs, aggregate nominal rigidities materialize through the wage bargaining process due to adjustment costs in the wage contracts.

3. Households own all domestic firms and the domestic capital stock, which they rent to domestic firms. There is a competitive market for capital, with capital accumulation subject to adjustment costs that also contribute to gradual economic adjustment. Labor and physical capital are immobile internationally. Households only trade short-term nominal bonds internationally and there are intermediation costs for households entering the bond market. These bonds are denominated in ROW dollars and issued in zero net supply worldwide.

\section{Firms}

4. Firms produce three types of goods: non-tradable final goods, non-tradable intermediate goods and tradable intermediate goods. The intermediate goods are produced in a monopolistically competitive market, using Cobb-Douglas production functions. As a result, prices contain a markup over marginal cost. The gradual adjustment of prices in response to economic disturbances observed in practice is achieved by introducing adjustment costs in the prices of intermediate goods along with nominal rigidities in wages.

\footnotetext{
${ }^{1}$ In the case of Estonia, the model is calibrated to ensure that the Estonian kroon is fixed against the euro and nominal interest rates are the same as in the EU.
} 
Intermediate non-tradable goods are used directly in the production of non-tradable final goods. Tradable intermediate goods are used either in the production of domestic nontradable final goods or in the production of foreign non-tradable final goods. Firms also provide financial intermediation services enabling households to trade in bonds.

5. The final good market is perfectly competitive. Firms use non-tradable and tradable intermediate goods (domestic and/or imported) as inputs in final good production. The final good either used for investment or consumed by domestic households or the government. In line with theory, international trade is driven by the interaction of preferences and relative prices, as the structure of final good production reflects the preferences of households and firms over intermediate goods.

\section{Government}

6. Government spending falls exclusively on final non-tradable goods. It is financed through a non-distorting consumption tax. The governments in the euro area and the ROW control their national short-term nominal interest rates with the objective of providing a nominal anchor and price stability for their economies. For Estonia, the nominal anchor is stability in the nominal exchange rate between the Estonian kroon and the euro.

\section{E. Parameterization}

7. Parameter values for GEM used in this note are calibrated. ${ }^{2}$ Several factors are taken into account during the calibration: empirical estimates available in the literature, the desired steady-state characterization of the economies, and the model's dynamic adjustment properties. Although the focus has been primarily on the steady-state characterization of the economies, attention was also given also to achieving plausible dynamic adjustment responses for some key variables. The key steady-state characteristics achieved in calibration are given in Table A1. ${ }^{3}$ The impulse responses for several key macroeconomic variables to a permanent one percentage point decline in the target rate of inflation and to a temporary increase in the short-term nominal interest rate are given in Figures A1 and A2 respectively, to provide an insight to the model's dynamic adjustment properties.

\footnotetext{
${ }^{2}$ Work is underway in the IMF's Research department to estimate GEM parameters by applying the Bayesian methods employed in Smets and Wouters (2002) and outlined in Schorfheide (2002) to enhance the data coherence of the model's parameter values.

${ }^{3}$ Full calibration of the model is available on request from the author.
} 
Figure A1. One Percentage Point Decline in the Euro Area Target Rate of Inflation (Percent or percentage point deviation from baseline)
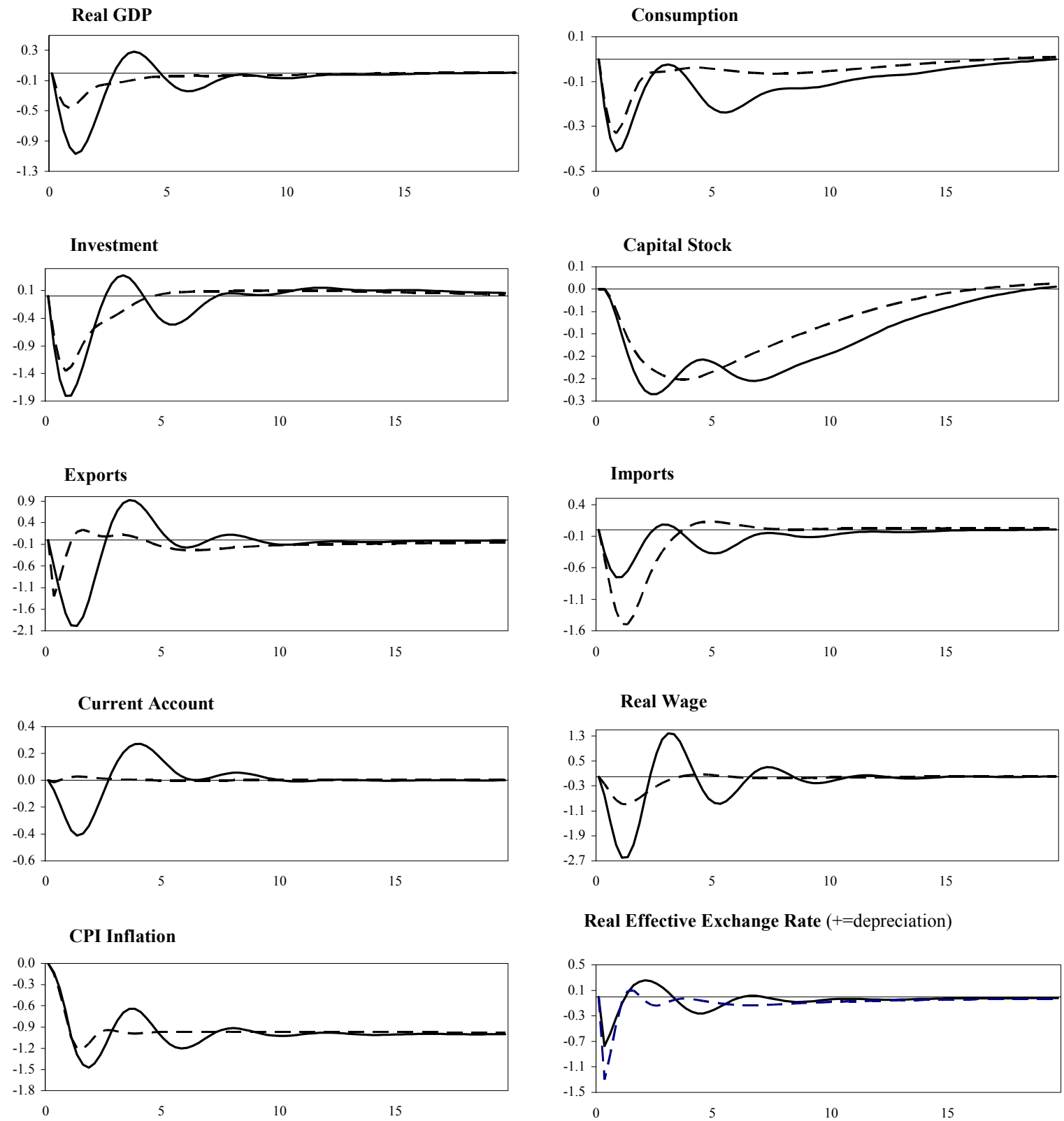

Real Effective Exchange Rate ( $+=$ depreciation)
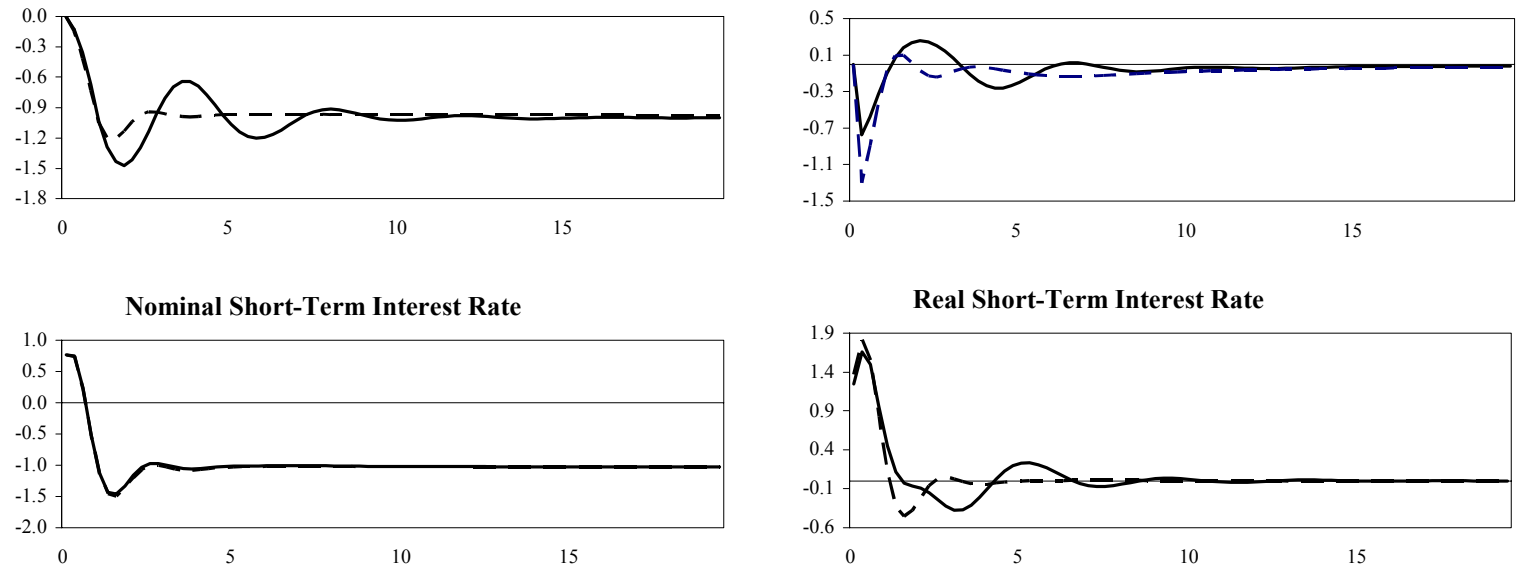

Estonia $=$ solid lines, Euro Area $=$ dashed lines, Number of quarters on horizontal axis 
Figure A2. One Percentage Point Increase in the EU Nominal Short-term Interest Rate (Percent or percentage point deviation from baseline)
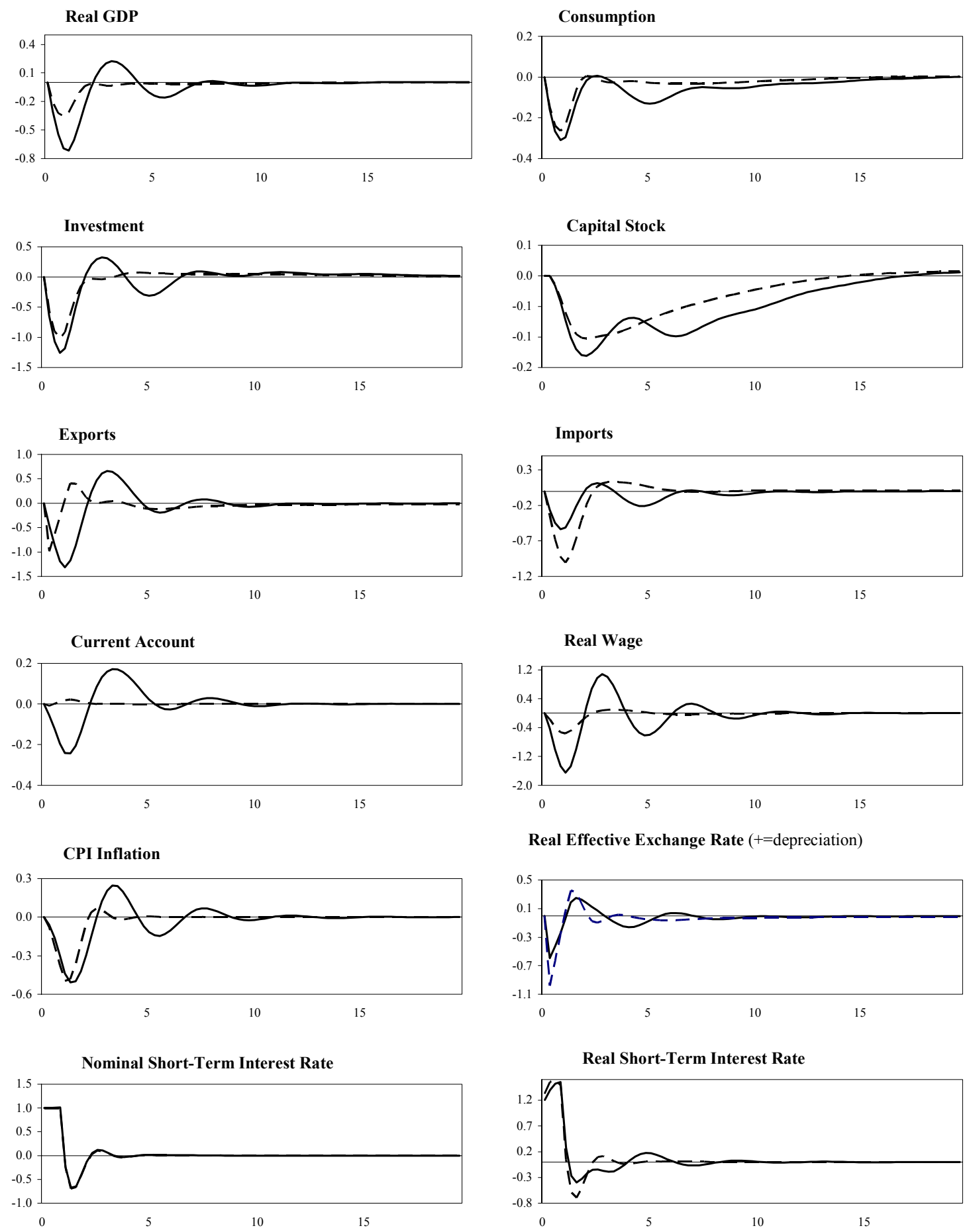

Estonia $=$ solid lines, Euro Area $=$ dashed lines, Number of quarters on horizontal axis 
Table A1. Calibration of the Steady-State 1/

\begin{tabular}{lccc}
\hline & Estonia & Euro area & Rest of the world \\
\hline Size, in percent (sum to unity) & 0.2 & 65.4 & 34.4 \\
Index of GDP per capita 2/ & 1.5 & 3.5 & 3.3 \\
& 56 & 58 & 59 \\
Private consumption & 19 & 20 & 20 \\
Public consumption & 26 & 22 & 21 \\
Investment & n.a. & 24.2 & 6.6 \\
Exports to Estonia & 0.10 & n.a. & 2.9 \\
Exports to Euro Area & 0.02 & 4.8 & n.a. \\
Exports to Rest of the world & 67 & 67 & 67 \\
Non-tradables & & & \\
\hline
\end{tabular}

1/ Calibrated using data for 2003

2/ Matches relative per capital GDPs of the three regions 